Universidade de São Paulo

Faculdade de Saúde Pública

\title{
Ação hipocolesterolêmica de hidrolisados de feijões caupi (Vigna unguiculata L. Walp)
}

\author{
Marcelo Rodrigues Marques
}

Dissertação apresentada ao Programa de pósgraduação em Nutrição em Saúde Pública para obtenção do título de Mestre em Ciências

Área de concentração: Nutrição em Saúde Pública

Orientador: Prof. Tit. José A. Gomes Arêas 


\title{
Ação hipocolesterolêmica de hidrolisados de feijões caupi (Vigna unguiculata L. Walp) (REVISADA)
}

\author{
Marcelo Rodrigues Marques
}

Dissertação apresentada ao Programa de pós-graduação em Nutrição em Saúde Pública para obtenção do título de Mestre em Ciências

Área de concentração: Nutrição em Saúde Pública

Orientador: Prof. Tit. José A. Gomes Arêas 
É expressamente proibida a comercialização deste documento, tanto na sua forma impressa como eletrônica. Sua reprodução total ou parcial é permitida exclusivamente para fins acadêmicos e científicos, desde que na reprodução figure a identificação do autor, título, instituição e ano da tese/dissertação. 


\section{DEDICATÓRIA}

Aos meus pais, Francisco (in memoriam) e Laura, por terem me dado à vida e apoiado incondicionalmente.

A minha esposa Evelyn por sua presença em minha vida

Dedico. 


\section{AGRADECIMENTOS}

A Deus, por me dar forças durante todo o tempo e ser onipresente em minha vida.

Ao professor José Alfredo por me receber em seu grupo e acreditar na minha capacidade de conduzir o trabalho.

Aos professores Dra. Débora Bastos e Dr. Daniel Pimenta, membros da banca examinadora, pelas valiosas sugestões e questionamentos, essenciais para a finalização e escrita deste trabalho.

À professora Regilda Araújo por despertar meu interesse acadêmico, ser minha primeira orientadora e além e tudo amiga.

À Dona Laura, minha amada mãe, que sempre apoiou meus sonhos, mesmo que eles não fizessem sentido, me mantendo perseverante.

A Evelyn, que por esse trabalho, abdicou de muitas coisas, caminhando junto a mim durante os momentos bons e ruins.

À minha irmã e meus sobrinhos e por estarem presentes quando precisei de carinho.

Aos colegas de laboratório, Cíntia, Bianka, Jéssica, Amanda, Thais, Nara Letícia, e Camila pela amizade, auxílio e momentos de descontração.

Agradeço especialmente à Cíntia e Bianka por ajudar na revisão final deste trabalho.

Ao Dr. Gustavo Fontanari, à nossa técnica Rosana Freitas pela amizade e disposição em auxiliar na parte experimental, ajudar na revisão, dar sugestões e pelas palavras de otimismo durante esta caminhada.

A Dra. Geni, Dra. Liânia, Érica Siguemoto, Érica Ferreira e todos do laboratório de bromatologia que dispensaram parte do tempo, conhecimento, paciência e convívio para nos abrigar durante a reforma do nosso laboratório.

A Áurea por ajudar a compreender extrusora, com o desenho experimental e pelas palavras de fé e amizade. 
Ao Bastos e sua esposa lara, que me receberam como um filho e aos funcionários do departamento de Nutrição pelo companheirismo e ajuda.

Aos meus amigos que ficaram em Teresina que mesmo longe continuam torcendo pelo meu sucesso.

À Fundação de Amparo à Pesquisa do Estado de São Paulo, pela bolsa recebida possibilitando a execução deste estudo.

A todos aqueles que contribuíram de alguma forma para o êxito desse trabalho. 
"A história da ciência ensina que o máximo que podemos esperar é um aperfeiçoamento sucessivo de nosso entendimento, mas com a condição de que a certeza absoluta sempre nos escapará." 


\section{RESUMO}

Introdução - Devido ao perfil de mortalidade e de danos patológicos associados, as doenças cardiovasculares são consideradas um sério problema de saúde pública. Níveis de colesterol plasmático elevados fazem parte dos fatores de risco mais importantes para 0 desenvolvimento dessas doenças. Pesquisas recentes demostraram que a proteína do feijão caupi promove a redução dos níveis de colesterol em hamsters e em seres humanos, possivelmente pela ação de peptídeos bioativos advindos da dieta. Entretanto, a via pela qual o colesterol é inibido por esses peptídeos, assim como os efeitos do processamento na ação biológica ainda são desconhecidos. Objetivo - Verificar a via de ação hipocolesterolêmica dos hidrolisados do feijão caupi e o efeito do processamento térmico nesta propriedade. Métodos - Parte da farinha integral foi submetida ao isolamento de proteína e o restante dos grãos foi submetido à cocção em autoclave e à extrusão. Após ser cozido em autoclave, o feijão cozido também teve sua proteína isolada. Posteriormente, a proteína isolada do feijão integral e do feijão cozido foi submetida à hidrólise in vitro. O processo de extrusão foi modelado em função da expansão dos extrusados segundo a metodologia de superfície de resposta. A farinha do feijão extrusado foi submetida à hidrólise enzimática in vitro sem isolamento prévio da proteína. Os três hidrolisados foram submetidos à ultrafiltração e a fração menor que $3 \mathrm{kDa}$ foi utilizada nos ensaios de inibição da enzima 3-hidroxi-3-metilglutaril coenzima A redutase (HMGR) e no ensaio de inibição da solubilização micelar do colesterol para avaliar a ação dos hidrolisados na via hepática e na via entérica do metabolismo do colesterol respectivamente. Resultados - Os hidrolisados provenientes dos isolados proteicos apresentaram comportamentos semelhantes. Em doses mais elevadas de proteína (acima de $70 \mu \mathrm{g} / \mathrm{mL}$ ), a inibição apresentou-se estável, por volta dos $75 \%$. Em relação ao hidrolisado da farinha de feijão extrusado, à medida que se aumenta a quantidade de proteína a capacidade inibitória diminui. Os hidrolisados foram capazes de inibir a solubilização micelar do colesterol de 5 a $39 \%$. O processamento térmico foi fator determinante para diminuir a solubilização do colesterol in vitro. Conclusão - Os hidrolisados do feijão caupi são capazes de inibir a enzima HMGR e reduzir a solubilização micelar do colesterol in vitro, mesmo após o feijão ser processado termicamente. A capacidade dos hidrolisados de insolubilizar o colesterol foi melhorada pelo cozimento em autoclave e pela extrusão.

Descritores: Feijão caupi, hidrolisados, extrusão. 


\section{ABSTRACT}

Introduction- The cardiovascular diseases, due to mortality and associated pathological damage, are considered a serious public health problem. Elevated plasma cholesterol levels are part of the most important risk factors for the development of these diseases. Recent research indicated that Cowpea protein promotes the reduction of cholesterol levels in hamsters and humans, possibly by the action of bioactive peptides from the diet. However, the route by which cholesterol is inhibited by peptides, as well as the processing effects on biological action are still unknown. Objective - To verify the hypocholesterolemic pathway of hydrolyzed cowpea and the effect of thermal processing on this property. Methods - Part of wholemeal flour was subjected to isolation of protein, and the remaining of the grains was subjected to retort and extrusion cooking processes. After autoclaving the grain, protein was also isolated from the flour. Subsequently, the isolated protein from wholemeal and cooked flour was subjected to in vitro hydrolysis. The extrusion process was optimized according to response surface methodology using the expansion ratio of extrudates as the dependent variable. The extruded bean flour was subjected to in vitro enzymatic hydrolysis without the isolation of the protein. The three hydrolysates were subjected to ultrafiltration and and fractions smaller than $3 \mathrm{kDa}$ was used for inhibition assays of the enzyme 3-hydroxy-3-methylglutaryl coenzyme A reductase (HMGR) and for inhibition assay of micellar solubilization of cholesterol to evaluate their effect on the liver and enteral cholesterol metabolism respectively. Results - The hydrolysates from the protein isolates showed similar. At higher doses of protein (above $70 \mathrm{mg} / \mathrm{mL}$ ), the inhibition was stable at around $75 \%$. Regarding the hydrolyzate of bean flour extruded as it increases the amount of protein inhibitory capacity decreases. The hydrolysates were able to inhibit the micellar solubilization of cholesterol between 5 and $39 \%$. The thermal processing was the determining factor to decrease the solubility of cholesterol in vitro.

Conclusion - The hydrolysates of cowpea are able to inhibit the enzyme HMGR micellar solubilization and reducing cholesterol in vitro, even after being thermally processed beans. The ability of hydrolysates insolubilize cholesterol was improved by cooking in an autoclave and by extrusion.

Key words: cowpea, hydrolysates, extrusion. 


\section{SUMÁRIO}

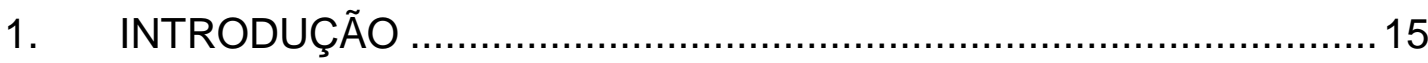

$1.1 \quad$ Metabolismo do colesterol ............................................................... 16

1.2 O efeito hipocolesterolêmico do feijão caupi e a ação de peptídeos bioativos

20

1.3. Extrusão de alimentos: mudanças físico-químicas durante o processo 23

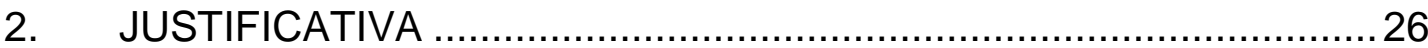

3. OBJETIVO

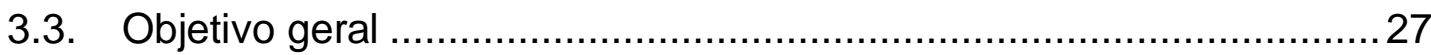

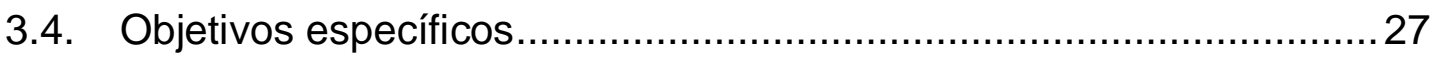

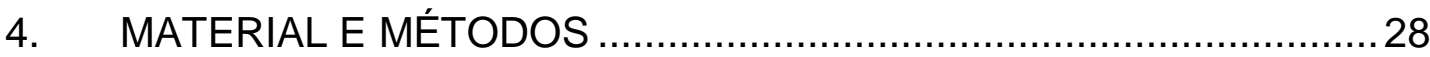

4.1. Obtenção da farinha do feijao caupi cru ...........................................28

4.2. Obtenção da farinha de feijão caupi cozido .....................................28

4.3. Modelagem do processo de extrusão e obtenção da farinha de

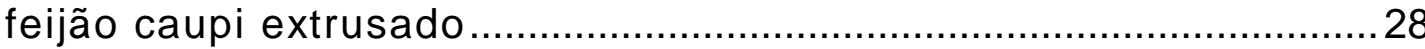

4.4. Obtenção dos isolados proteicos a partir das farinhas ........................32

4.5. Composição centesimal e fibras ................................................ 34

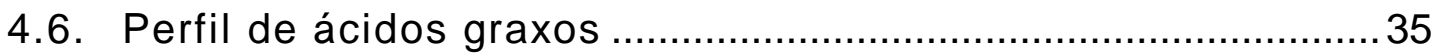

4.7. Hidrólise in vitro do IPcru, IPcoz e da Fex ...............................35

4.8. Determinação do grau de hidrólise ..........................................36

4.9. Perfis dos hidrolisados em cromatografia líquida de alta eficiência (CLAE) .........................................................................

4.10. Ensaio de inibição da enzima HMGR in vitro...................................38

4.11. Ensaio da inibição da solubilização micelar do colesterol in

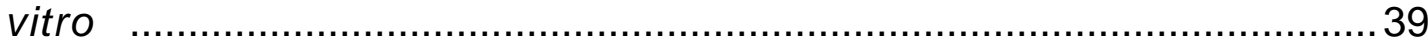

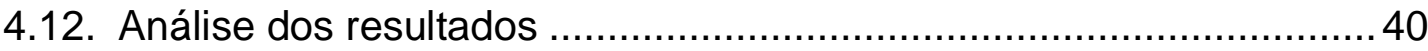

5. RESULTADOS E DISCUSSÃO ..................................................... 41

5.1. Testes exploratórios e modelagem do processo de extrusão .....41

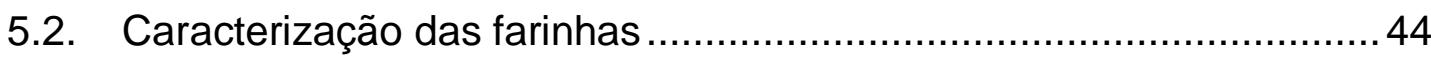

5.3. Caracterização dos isolados proteicos ...........................................47

5.5. Inibição da enzima HMGR por hidrolisados de feijão caupi ...............51

5.5.1. Hidrolisados provenientes dos isolados proteicos (IPcru e IPcoz) .....51

5.5.2. Hidrolisado proveniente da farinha de feijão extrusado (Fex) .............53

5.6. Inibição da solubilização micelar do colesterol in vitro ............54

5.6.1. Hidrolisados provenientes dos isolados proteicos (IPcru e IPcoz) .....54 
5.6.2. Hidrolisado proveniente da farinha de feijão extrusado (Fex). .55

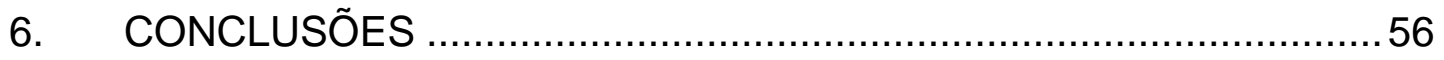

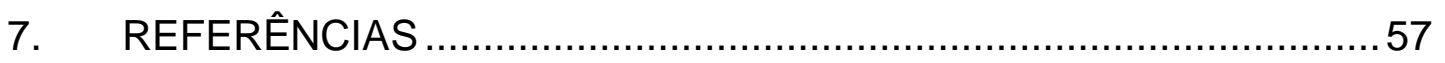

APÊNCIDE 1- Efeito da temperatura e da umidade da matéria-prima sobre a razão de expansão dos extrusados.

APÊNDICE 2- Efeito da temperatura e da velocidade de rotação da sobre a razão de expansão dos extrusados. 68

APÊNDICE 3-Estimativa dos efeitos das variáveis independetentes na razão de expansão da farinha extrusada de caupi.............................................69

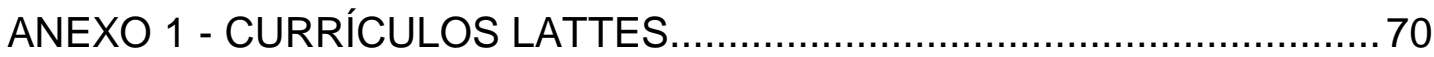




\section{LISTA DE TABELAS}

Tabela 1 - Matriz do planejamento fatorial $2^{3}$ com repetição do ponto central.

Tabela 2 - Análise de variância para o ajuste do modelo linear aos dados da razão de expansão dos extrusados.

Tabela 3 - Modelo de regressão para razão de expansão da farinha de feijão caupi*. 42

Tabela 4 - Composição centesimal $\left(\mathrm{g} .100 \mathrm{~g}^{-1}\right)$ e valor energético ( $\left.\mathrm{kJ} .100 \mathrm{~g}^{-1}\right)$ das farinhas Fcru, Fcox e Fex em base seca*.

Tabela 5 - Perfil de ácidos graxos das farinhas Fcru, Fcoz e Fex expressos em mg de ácidos graxos $/ 100 \mathrm{~g}$ de amostra.

Tabela 6 - Composição centesimal $\left(\mathrm{g} .100 \mathrm{~g}^{-1}\right)$ dos isolados proteicos da Fcru e Fcoz em base seca.

Tabela 7 - Percentual de inibição da solubilização micelar do colesterol na presença dos hidrolisados. Média \pm Desvio-padrão. 


\section{LISTA DE FIGURAS}

Figura 1 - Representação simples da biossíntese de novo de colesterol em células animais. Adaptado de Mathew, Yoshida et al. (2011).

Figura 3 - Extrusora de laboratório ELM20-MIOTTO

Figura 2 - Fluxograma do isolamento proteico das farinhas de feijão caupi crua e cozida.

Figura 4 - Fluxograma das etapas para obtenção dos hidrolisados.

Figura 5 - Aparência final do feijão extrusado.

Figura 6 - Perfil de ácidos graxos das farinhas integral, cozida e extrusada de feijão caupi segundo grau de saturação (AGS - ácidos graxos saturados; AGM - ácidos graxos monoinsaturados; AGP - ácidos graxos poli-insaturados).

Figura 7 - Cromatogramas a $220 \mathrm{~nm}$ dos hidrolisados do IPcru 50

Figura 8 - Cromatogramas a $220 \mathrm{~nm}$ dos hidrolisados do IPcoz.... 50

Figura 9 - Cromatogramas a 220 nm dos hidrolisados da Fex.

Figura 10 - Percentual de inibição da enzima HMGR na presença dos hidrolisados de feijão caupi segundo processamento. Média \pm Desvio-padrão. .52 


\section{LISTA DE ABREVIATURAS E SIGLAS}

$\begin{array}{lll}\text { Alanina } & \text { Ala } & \text { A } \\ \text { Cisteína } & \text { Cys } & \text { C } \\ \text { Ácido Aspártico } & \text { Asp } & \text { D } \\ \text { Ácido Glutâmico } & \text { Glu } & \text { E } \\ \text { Fenilalanina } & \text { Phe } & \text { F } \\ \text { Glicina } & \text { Gly } & \text { G } \\ \text { Histidina } & \text { His } & \text { H } \\ \text { Isoleucina } & \text { Ile } & \text { I } \\ \text { Lisina } & \text { Lys } & \text { K } \\ \text { Leucina } & \text { Leu } & \text { L } \\ \text { Metionina } & \text { Met } & \text { M } \\ \text { Asparagina } & \text { Asn } & \text { N } \\ \text { Prolina } & \text { Pro } & \text { P } \\ \text { Glutamina } & \text { Gln } & \text { Q } \\ \text { Arginina } & \text { Arg } & \text { R } \\ \text { Serina } & \text { Ser } & \mathrm{S} \\ \text { Treonina } & \text { Thr } & \text { T } \\ \text { Valina } & \text { Val } & \text { V } \\ \text { Triptofano } & \text { Trp } ~ & \text { W } \\ \text { Tirosina } & \text { Tyr } & \text { Y }\end{array}$


Fex Farinha de feijão extrusado

Fcru Farinha de feijão cru

Fcoz Farinha de feijão cozido

IPcru Isolado proteico da Fcru

IPcoz Isolado proteico da Fcoz

AGM Ácidos graxos monoinsaturados

AGP Ácidos graxos poliinsaturados

AGS Ácidos graxos saturados

HDL Lipoproteína de alta densidade

LDL Lipoproteína de baixa densidade

VLDL Lipoproteína de muito baixa densidade

LDLr Receptor de LDL

SREBP Sterol Regulatory Element Binding Proteins

HMG-CoA 3-Hidroxi-3-metilglutaril coenzima A

HMGR 3-Hidroxi-3-metilglutaril coenzima A redutase

NADPH Nicotinamida adenina dinucleotídeo fosfato reduzido

$\mathrm{NADP}^{+} \quad$ Nicotinamida adenina dinucleotídeo fosfato oxidado

CoA-SH Coenzima A desacilada 


\section{INTRODUÇÃO}

As doenças cardiovasculares, devido ao perfil de mortalidade e de danos patológicos associados, são consideradas um sério problema de Saúde Pública. Devido a isso, início do século 20, mais enfaticamente a partir da década de 80 no Japão, motivado por um aumento da incidência de doenças crônicas fortemente associadas com alimentação inadequada e ao estilo de vida, a capacidade dos alimentos de exercer efeitos benéficos na saúde começou a ser estudada (DURÁN C e VALENZUELA B, 2010).

Devido a isso, os próprios alimentos e ingredientes alimentares vêm sendo estudados com o intuito de reduzir do risco do desenvolvimento dessas doenças. Conhecidos como alimentos funcionais, essas matrizes alimentares possuem uma gama de compostos responsáveis por tais efeitos fisiológicos (MARQUES et al., 2012; LANDETE, 2012).

Nesse contexto, Ivanov (1997) foi um dos primeiros pesquisadores a sugerir o fato de que proteínas poderiam atuar na homeostase, agindo em tecidos específicos. Atualmente, frações peptídicas codificadas dentro de proteínas alimentares resultantes da digestão por enzimas naturais e sintéticas são reconhecidas, identificadas e descritas como antimicrobianas, antifúngicas, antioxidantes, antitrombóticas, imunomodulatórias, opióides e também hipocolesterolêmicas (PIMENTA e LEBRUN, 2007; FERREIRA et al., 2011; HERNANDEZ-LEDESMA, CONTRERAS e RECIO, 2011).

O potencial hipocolesterolêmico de algumas leguminosas já é conhecido. $O$ consumo da proteína de soja é capaz de reduzir o colesterol sanguíneo, provavelmente por ação dos peptídeos encriptados na proteína, liberados após digestão enzimática in vitro ou in vivo, (POTTER, 1998; PAK, KOO, KASYMOVA, et al., 2005).

Existem especulações acerca dos mais variados mecanismos relacionados à ação de peptídeos no metabolismo do colesterol, como por exemplo, agindo de forma similar a hormônios, inibindo competitivamente à enzima 3-Hidroxi-3-metilglutaril coenzima A redutase (HMGR) no fígado, suprimindo a expressão de genes que estariam relacionados ao metabolismo de ácidos graxos e 
impedindo a solubilidade micelar do colesterol no lúmen, levando à redução de lipídeos plasmáticos e hepáticos (ARNOLDI et al., 2001; PAK et al., 2006; FROTA, 2007; SOARES, 2008).

Acompanhando o avanço científico, as indústrias de alimentos têm incorporado nos seus produtos diversos compostos bioativos por meio do processamento ou melhorando a biodisponibilidade desses compostos. Utilizam para tal, matérias-primas que geralmente seriam rejeitados pelo sabor não agradável e/ou por não participarem da dieta habitual do indivíduo (CHAVEZ-JAUREGUI et al., 2003; MOREIRA-ARAUJO, ARAUJO e AREAS, 2008; FROTA et al., 2010; BOMBO TREVISAN e AREAS, 2012).

O processo de extrusão é largamente utilizado pela indústria na produção de petiscos; macarrões; alimentos à base de cereais enriquecidos com proteína; bebidas em pó; produtos texturizados em geral como farinhas e amidos prégelatinizados utilizados na formulação de sopas instantâneas; molhos semiprocessados; produtos de confeitaria; amidos modificados; alimentos infantis; cereais matinais e snacks, servindo como meio mais fácil de incorporar alimentos em uma dieta habitual (CHANG et al., 1999; ALVIM, SGARBIERI e CHANG, 2002; FERNANDES et al., 2003). Portanto, a extrusão termoplástica apresenta-se como uma alternativa para o desenvolvimento de alimentos que contemplem propriedades nutritivas e bioativas, facilitando a digestão após processamento.

\subsection{Metabolismo do colesterol}

O primeiro esterol conhecido, o colesterol, foi descoberto por químicos franceses como um componente de cálculos biliares humanos há mais de 230 anos. Foi inicialmente denominado de "cholesterine", derivado de duas palavras gregas, literalmente traduzidas por "bile sólida". Em países de língua inglesa, o nome foi substituído por colesterol após o reconhecimento de que a substância era um álcool secundário. A fórmula correta levou mais 30 anos para estabelecer a exata representação espacial da molécula levando Wieland e Windaus ao Prêmio Nobel de Química (1927 e 1928). A primeira ligação entre o colesterol e a saúde humana 
apareceu em 1843. Os autores visualizaram a presença de colesterol organizado em placas nas artérias (POPJAK., 1986; NES, 2011).

A compartimentalização e o transporte de colesterol é uma homeostase complexa, dado o fato do código genético humano não codificar esteróis, as mudanças na atividade de várias proteínas transportadoras (Quilomícrons, VLDL, IDL, LDL, HDL) e proteínas de membrana (ABC e NPC) refletem indiretamente a homeostase, objetivando a estabilidade da concentração endógena de colesterol, ao equilibrar fontes internas e externas (GOLDSTEIN e BROWN, 1990; FITZGERALD et al., 2011).

Dois passos principais são considerados como críticos para a manutenção da concentração de colesterol total: a sua síntese no fígado e a circulação enterohepática com a secreção do colesterol na bílis e a sua reabsorção parcial, em conjunto com colesterol da dieta, na parte superior do intestino.

Está bem estabelecido que, para que ocorra a absorção entérica de colesterol o organismo promove antes uma emulsificação, formando micelas mistas de sais biliares e lipídeos, além de contar com mecanismos passivos baseados no equilíbrio relativamente rápido entre o colesterol e os conjuntos hidrofóbicos dos constituintes micelares (CORETA-GOMES et al., 2012). As micelas são caracterizadas como agregados poli moleculares de característica anfipática, por essa razão, além de serem solúveis em água, são capazes de facilitar o transporte intraluminal e a absorção de lipídeos através da borda em escova das células intestinais (MARRINK e MARK, 2002).

Embora estudos iniciais indicassem que o lúmen intestinal continha principalmente micelas, os estudos mais recentes demonstram a presença no lúmen de uma variedade de partículas de diferentes tamanhos após uma refeição. Dois grandes agregados macromoleculares parecem estar envolvidos com a absorção de lipídeos dentro do lúmen intestinal: as vesículas unilamelares são partículas maiores, pobres em ácidos biliares possuindo várias centenas de angstroms de diâmetro e contêm fosfolipídeos, ácidos graxos, monoglicerídeos e colesterol. As micelas mistas são muito mais ricas em ácidos biliares, são partículas menores com diâmetros inferiores a 100 angstroms e são compostas principalmente de ácidos biliares e colesterol com menores quantidades de fosfolipídeos (WOOLLETT et al., 2006). 
Os ácidos biliares também existem como formas monoméricas em concentrações muito baixas. Diferentes tipos de agregados parecem estar presentes num fluido que desloca o equilíbrio entre partículas de diferentes tamanhos, como a concentração de ácidos biliares e outros componentes lipídicos no lúmen. Quando as concentrações de ácidos biliares excedem a concentração micelar crítica (CMC), as micelas se formam apenas por ácidos biliares. Concentrações de ácidos biliares abaixo da CMC resultam em equilíbrio, preferencial para a formação de vesículas. A inibição desse equilíbrio, por meio da insolubilização do colesterol nas micelas, pode ser alterada por produtos alimentícios e é um tema de atual interesse de pesquisas que objetivam o tratamento da hipercolesterolemia (WOOLLETT et al., 2006).

Após a emulsificação, a absorção entérica do colesterol é mediada por transportadores de membrana, por mecanismos ainda pouco conhecidos, em que proteínas NPC1L-1 são as principais responsáveis pela absorção de colesterol micelar no lúmen. De forma antagônica, as proteínas de transporte ABCA1, ABCG1 e ABCG5/G8, regulam o efluxo de colesterol tanto nos enterócitos como nas células do fígado, ao transladá-lo na forma de HDL para o meio extracelular. Igualmente importante, os receptores de LDL nas células hepáticas, realizam o retorno de colesterol dos tecidos para o fígado e acabam inibindo a enzima HMGR e a síntese de colesterol por mecanismo de retroalimentação (feed back). Esses transportadores são regulados de forma homeostática, expressos geneticamente segundo a necessidade ou não de colesterol nos diversos compartimentos e tecidos (TACHIBANA et al., 2007; KIDAMBI e PATEL, 2008; FITZGERALD et al., 2011).

Em células animais, potencialmente todos os tecidos possuem a capacidade de produzir colesterol, como o intestino, os tecidos reprodutivos, o córtex adrenal, mas a produção majoritária se encontra no fígado e é denominada síntese de novo de colesterol pela via do mevalonato (COSKUN, SERTESER e Unsal, 2013). 


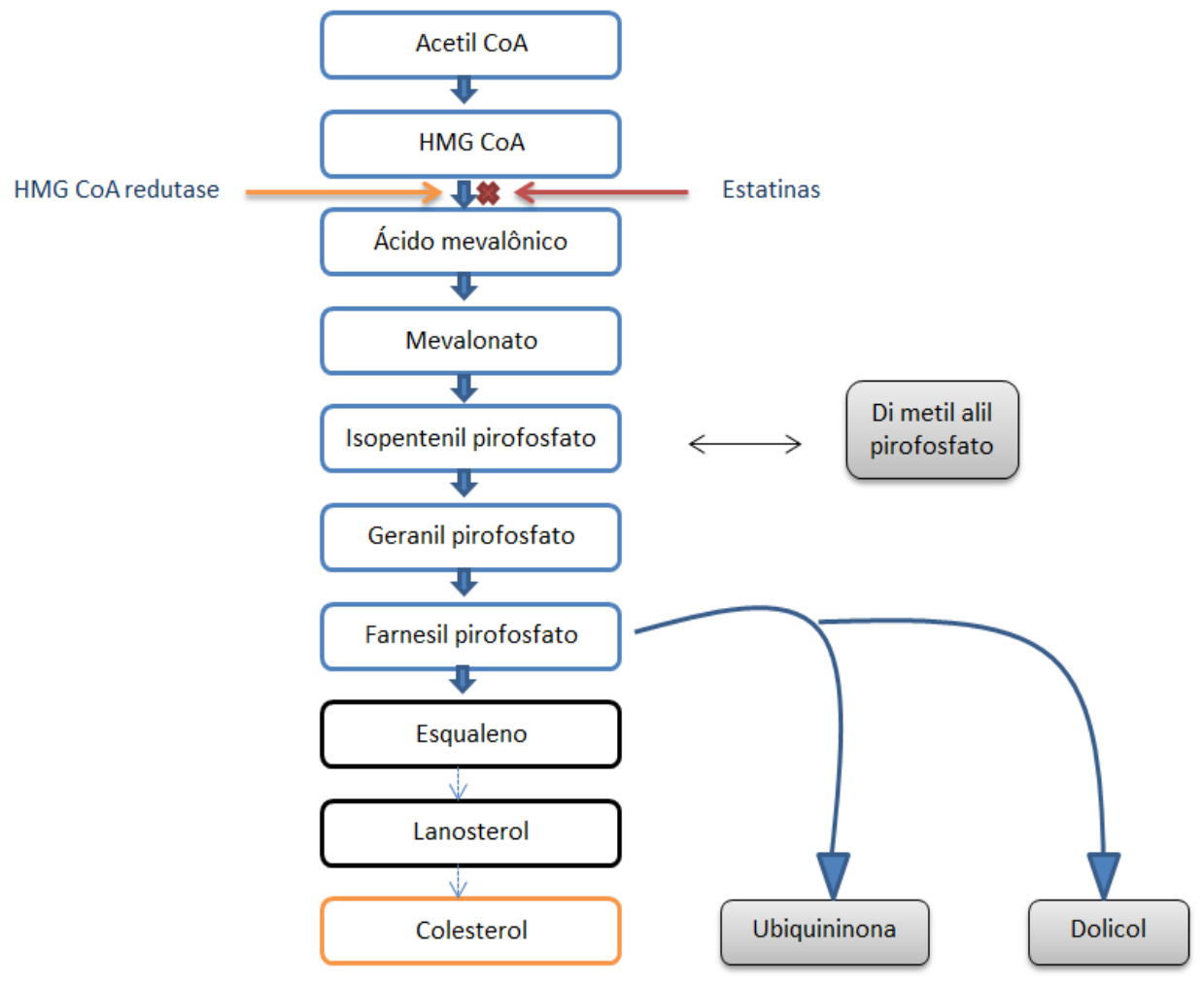

Figura 1 - Representação simples da biossíntese de novo de colesterol em células animais. Adaptado de Mathew, Yoshida et al. (2011).

A biossíntese do colesterol compreende mais de 20 reações catalisadas enzimaticamente e ocorre em quatro etapas principais. Na primeira fase, as moléculas de acetilcoenzima $A$ (acetil $\mathrm{CoA}$ ) forma uma molécula de seis carbonos chamada mevalonato. Na segunda etapa, mevalonato é convertido em unidades de isopreno, os quais são ativados posteriormente (etapa 3) e polimerizados para formar esqualeno. Na quarta e última fase, a ciclização de esqualeno forma o núcleo esteroide e uma série adicional de alterações leva à formação de colesterol (MATHEW et al., 2011; YOSHIDA et al. 2011; COSKUN, SERTESER e UNSAL, 2013).

O passo limitante da velocidade da via do mevalonato é a conversão de 3-hidroxi-3-metilglutaril coenzima A (HMG-CoA) em mevalonato catalisada pela 3-hidroxi-3-metilglutaril coenzima A redutase (HMGR). Essa via é regulada por retroalimentação quando há ingestão dietética de colesterol e, em consequência disso, também pelos receptores de absorção plasmática de LDL. Quando esses dois 
componentes estão elevados, a HMGR é inibida e a formação de mevalonato é interrompida. Complementarmente, o colesterol em excesso é desviado para a produção de outros derivados como ácidos biliares, vitamina $D$, hormônios esteroides, com o intuito de manter a homeostase (GOLDSTEIN e BROWN, 1990; IKONEN, 2008).

Esse ponto de controle enzimático da via possui sua importância pelo fato de que atualmente, a forma mais utilizada para o tratamento da hipercolesterolemia é com administração fármacos denominados de estatinas. As estatinas são um grupo de drogas (simvastatina, lovastatina, mevastatina, atorvastatina, pravastatina), que inibem a biossíntese do colesterol. Estas drogas inibem HMGR por ligação ao local ativo da enzima, evitando a ligação do substrato, auxiliando na diminuição dos níveis de colesterol no sangue, proteção contra a oxidação de lipoproteínas de baixa densidade, bem como efeitos anti-inflamatórios e redução no nível de proteína $C$ reativa (ISTVAN e DEISENHOFER, 2001; COSKUN, SERTESER e UNSAL, 2013).

\subsection{0 efeito hipocolesterolêmico do feijão caupi e a ação de peptídeos bioativos}

O feijão caupi é uma dicotiledônea que pertence à ordem Fabales, família Fabaceae, subfamília Faboideae, tribo Phaseoleae, subtribo Phaseolinea e ao gênero Vigna. Constituindo-se na principal cultura de subsistência das regiões Norte e Nordeste brasileiro, exerce a função social de ser alimento frequente no hábito alimentar de famílias de baixa renda (IBGE, 2002; MOUSINHO, 2005; FROTA et al., 2010). As formas cultivadas no Brasil são conhecidas com os mais variados nomes como: feijão de praia, feijão de rama, feijão fradinho, sendo os mais comuns, feijão macassar, feijão de corda ou caupi e feijão de metro (FREIRE FILHO et al., 1981; Embrapa, 1987; IBGE, 2002).

Em seu estudo, Frota et al. (2008), produziram isolado proteico de feijão caupi e verificaram a influência da proteína isolada no metabolismo lipídico de hamsters hipercolesterolemizados. Comparada à dieta controle com caseína, a dieta contendo 
$20 \%$ de isolado proteico provocou redução significativa no colesterol total (20\%) e colesterol não-HDL (22 \%).

Entretanto, o mecanismo pelo qual o isolado proteico do feijão caupi exerce efeito hepatoprotetor e hipocolesterolemizante ainda não está totalmente esclarecido, pois, de acordo com o trabalho de Frota et al. (2008), nenhuma diferença significativa foi encontrada na excreção de colesterol total e ácido biliares nas fezes dos animais que consumiram o isolado. Comparado ao grupo que consumiu o feijão integral, não houve diferenças no aumento de bolo fecal.

Um shake contendo isolado proteico de feijão de corda foi administrado por Frota (2011) em humanos para confirmar os estudos realizados com hamsters. Os resultados do estudo são consistentes com evidências de que o consumo de sua proteína provoca efeitos hipocolesterolemizante e indica que o consumo de $25 \mathrm{~g} / \mathrm{dia}$ de proteína de feijão caupi por indivíduo adulto hipercolesterolêmicos, sem alterar estilo de vida, é capaz de modificar o perfil lipídico principalmente no que se refere à redução de colesterol total, LDL colesterol, colesterol não-HDL e discreto aumento do HDL colesterol.

No estudo de fontes alimentares, tem sido demonstrado que os peptídeos têm efeitos positivos sobre a saúde, funcionando como anti-hipertensivos, antioxidantes, anticancerígenos, antimicrobianos e anticariogênicos, entre outros. Estas propriedades fizeram com que ficassem conhecidos como peptídeos funcionais ou biologicamente ativos (ou seja, bioativos). Após o processamento enzimático, sequências de aminoácidos que estavam inativas no núcleo da proteína de origem são liberadas e podem exercer propriedades especiais. Os peptídeos bioativos são componentes vitais de alimentos funcionais, uma área de pesquisa de grande interesse devido ao seu valor terapêutico (SEGURA-CAMPOS et al., 2011).

Kwak et al. (2012) demonstraram a ação de peptídeos da soja, após suplementação, na redução do peso, IMC, perfil lipídico, níveis de insulina e de produção da leptina em humanos. Ghassem et al. (2012) isolaram e purificaram, após hidrólise enzimática de proteína de bagre, as sequencias peptídicas GPPP e IEKPP que mostraram a capacidade de inibir a enzima conversora de angiotensina in vitro. O peptídeo denominado lactostatina, derivado do leite de vaca, é reconhecidamente um peptídeo redutor da síntese do colesterol no fígado (WAKASA et al., 2011) 
Nesse contexto, os fragmentos peptídicos com as sequências IAEK, VPDPR, IAVP, e LPYPR apresentam comprovada capacidade hipocolesterolemizante por se complexarem com a hidroxi-3-metil-glutaril-CoA redutase (HMGR) e consequenteme nte diminuindo a biossíntese endógena de colesterol. Esses peptídeos podem ser encontrados em produtos de origem vegetal como a soja, o trigo, o agrião, o arroz, a ervilha, entre outros, porém ainda não foi descrito a existência dessas sequencias de tetra e pentapeptídeos no feijão de corda ou caupi (DZIUBA, IWANIAK E MINKIEWICZ, 2003; ERDMANN, CHEUNG e SCHRODER, 2008).

Atualmente, são desenvolvidos fármacos, que são na realidade peptídeos sintéticos baseados em sequencias encontradas nas proteínas vegetais, mimetizando a estrutura conformacional da enzima e atuando também como inibidoras por competição de sítios específicos da molécula de HMGR (PAK et al., 2006).

Um estudo recente isolou a proteína do feijão caupi e utilizou-se da cromatografia em gel para purificar, quantificar e medir atividade inibitória de peptídeos inibidores da enzima conversora de angiotensina (ECA-I). Os autores concluiram que os hidrolisados proteicos do feijão de corda possuem atividade de inibir a ECA, podendo ser purificadas e utilizadas como componentes de alimentos funcionais anti-hipertensivos (SEGURA-CAMPOS, CHEL-GUERRERO e BETANCUR-ANCONA, 2011).

A modulação da absorção do colesterol por hidrolisados e fontes alimentícias é também um dos mecanismos estudados para explicar a atuação dos alimentos na redução do colesterol plasmático. Pesquisas indicam que o consumo de determinados alimentos, ou hidrolisados alimentícios, pode impedir a absorção entérica de colesterol, perturbando a conformação das micelas de colesterol e ácidos biliares, por competição e/ou aumentando o tamanho das vesículas bem como agindo sobre a expressão das proteínas de membrana responsáveis pela absorção (MEGÍAS et al., 2009; PETRUZZELLI et al., 2009; ZHANG, YOKOYAMA e ZHANG, 2012)

A ingestão de peptídeos, proteínas e hidrolisados provenientes de algumas fontes vegetais seria, portanto, uma possível estratégia na perspectiva da diminuição dos níveis de colesterol plasmático e o risco para doenças cardiovasculares. Porém, com o advento da transição nutricional brasileira e mundial, verifica-se ao longo do 
tempo um decréscimo no consumo de leguminosas integrais associado ao aumento do consumo de alimentos industrializados (BRASIL., 2006).

\subsection{Extrusão de alimentos: mudanças físico-químicas durante o processo}

A tecnologia de extrusão surgiu no século XVIII, com a patente da primeira extrusora, por Joseph Bramah em 1797 para o fabrico de plásticos, metais e materiais sintéticos. $\mathrm{Na}$ indústria alimentícia foi utilizada primeiramente para o processamento de carnes e uso em indústrias de macarrões, servindo apenas para pré-cozinhar e dar forma a pastas alimentícias. A partir da década de 30 e 40 é que foram produzidos alimentos ready-to-eat (prontos para o consumo). A extrusora passou a ganhar a versatilidade conhecida atualmente ao produzir snacks a partir do uso do milho. Após as décadas de 50 e 60, o cozimento por extrusão passou a resultar também em pet foods, cereais matinais e em blends alimentícios, dando origem a diversos produtos (HARPER, 1981; BRENNAN et al., 2013).

Sinteticamente, a extrusão de alimentos consiste na rotação contínua de um parafuso de Arquimedes dentro de um cilindro ou canhão, que com o auxílio do aquecimento, promovido por resistências elétricas, proporciona atrito e grande força de cisalhamento, transformando o material sólido em fluido, cozinhando a matériaprima a alta pressão ao mesmo tempo em que a comprime contra um tipo de abertura milimétrica chamada de matriz (SINGH, GAMLATH e WAKELING, 2007).

Existem três principais tipos de roscas ou rosca: rosca único, rosca duplarosca (co-rotante ou contra-rotante) e cônico. Independentemente do tipo rosca que é usado, ele roda constantemente no interior do tambor (cilindro ou barril) durante a extrusão, fazendo com que o material se movimente em um único sentido, proporcionando pressão e cisalhamento contínuos. Os ingredientes são transportados através da ação da rotação do (s) rosca(s) promovendo forças de cisalhamento e de arrasto ao longo do canhão, em geral, num fluxo laminar. Dependendo da construção da rosca de extrusão, podem ser montadas ranhuras que aumentem o fluxo do material para trás, fazendo com que uma quantidade limitada de material retroaja e misture novamente. A extrusora com rosca única é 
mais comumente usada, pois é simples de usar e possui menores custos (BRENNAN et al., 2013).

O atrito e perturbação estrutural intensa facilitam a modificação das propriedades funcionais dos ingredientes alimentares e/ou a texturização, transformando-os em biopolímeros rearranjados, desnaturando enzimas indesejáveis (inibidores de tripsina), elimimnando fatores antinutricionais e esterilizando o produto acabado (KELKAR et al., 2012). Além disso, a operacionalização da extrusora é composta por variáveis ajustáveis capazes de influenciar todo o processo, como velocidade de rotação da rosca, umidade da matéria prima, temperatura, pressão, taxa de compressão e até a vibração sonora produzida pelo equipamento pode modificar o produto final, produzindo mudanças físicas, químicas e sensoriais (KRAUGERUD, JØRGENSEN e SVIHUS, 2011; SAELEAW, DURRSCHMID e SCHLEINING, 2012).

O processamento de alimentos pelo calor, seja qual for, imprime diferentes graus de modificações organolépticas, podendo ser desejáveis, como cor, aroma e flavor advindos da reação de Maillard e/ou da caramelização, e também indesejáveis, como a produção de aminas heterocíclicas ou simplesmente mudanças na composição original do alimento promovendo percas nutricionais ou sensoriais (MARMESAT et al., 2012).

A extrusão termoplástica de alimentos promove mudanças na composição de macronutrientes dos extrusados. Os carboidratos são os mais importantes constituintes do alimento capazes de afetar a qualidade sensorial e expansão dos extrusados. Um dos carboidratos mais importantes para a extrusão é o amido. $O$ amido é um grânulo semi-cristalino composto de dois polímeros de glicose, amilose e amilopectina, que necessita ser gelatinizado para ativar suas propriedades funcionais. A quantidade de energia incorporada na massa alimentícia rica em amido dentro do canhão causa mudanças na viscosidade devido a alterações estruturais e de plasticização de proteínas e amido, alterando inclusive a proporção de amilose e amilopectina inicial influenciando diretamente na dureza do alimento final. As mudanças ocorridas favorecem a digestão do amido, deixando os grânulos mais suscetíveis à ação enzimática, ou dependendo do teor de umidade incorporada, dificultando-a, por retrogradação (MAHASUKHONTHACHAT, SOPADE e GIDLEY, 2010; SORENSEN et al., 2011). 
Os lipídeos são os componentes que desempenham um papel importante na maior parte dos processos de extrusão. Eles podem atuar como plastificantes ou emulsionantes e afetam a textura e viscosidade dos extrusados. Os óleos e as gorduras proporcionam um efeito poderoso lubrificante na mistura de polímero durante o cozimento. Sob condições de cozimento de extrusão, todos os lipídeos tornam-se óleos com o aumento da temperatura de massa que diminui seus pontos de fusão. Porém, a adição de pelo menos $5 \%$ de óleo vegetal pode prejudicar a expansão dos extrusados. Em cereais e alimentos ricos em amido, a complexação amilose-lipídeo dificulta a obtenção de extrusados expandidos (ILO, REGINE e BERGHOFE, 2000; ALSAFFAR, 2011; DE PILLI et al., 2012).

Nutricionalmente, o uso de altas temperaturas pode promover a formação de peróxidos com consequente oxidação lipídica, provavelmente por causa da presença na massa alimentícia de metais catalizadores e da destruição e alguns antioxidantes naturais. De forma oposta, as temperaturas utilizadas no cozimento destroem as lipooxigenases, responsáveis pela oxidação enzimática. De uma forma geral, os extrusados possuem composição pobre em lipídeos, em torno de 2 a $5 \%$, pois nesse percentual são capazes de emulsificar satisfatoriamente sem prejudicar a expansão do produto (ILO, REGINE e BERGHOFE, 2000).

Quanto às proteínas, as maiores alterações estão diretamente ligada a desnaturação proteica que ocorre no processo. A desnaturação altera a conformação espacial da proteína de inibidores de enzimas digestivas naturalmente presente em alimentos vegetais, como soja, feijão e amendoim. Estas alterações possibilitam o uso da extrusão como uma forma para reduzir a quantidade de alérgenos em alimentos (ALVAREZ-ALVAREZ ET AL., 2005; CONTI E SILVA, DA CRUZ e GOMES AREAS, 2010).

O aumento no consumo e demanda por produtos saudáveis exige uma adaptação da indústria de alimentos, que a cada dia reformula sua produção, para incorporar em seus produtos componentes funcionais (CAMIRE, DOUGHERTY e BRIGGS, 2007; ANUONYe et al., 2010; BRENNAN, DERBYSHIRE, BRENNAN, et al., 2012).

Mesmo considerando as perdas que ocorrem no processo, a incorporação de proteínas provenientes de fontes alimentares com propriedades bioativas é inovadora. Entretanto, a maioria dos estudos não considerara o efeito do 
processamento na ação biológica das proteínas, em especial, após a extrusão (CAMPOS, GUERRERO e ANCONA, 2010; DESCAMPS et al., 2011).

\section{JUSTIFICATIVA}

As doenças crônicas relacionadas ao estilo de vida são consideradas um sério problema de Saúde Pública. Por causa disso, é crescente o interesse pelo valor nutricional de alimentos tradicionais com foco em alimentos funcionais.

Apesar da proteína do feijão caupi possuir capacidade hipocolesterolêmica, não se sabe ao certo qual é o mecanismo no qual a proteína atua promovendo a diminuição do colesterol.

A facilidade com que os fatores antinutricionais do feijão podem ser destruídos pelo calor, popularizou seu consumo como uma fonte de proteína na dieta humana, no entanto, o efeito hipocolesterolêmico da proteína do feijão caupi ainda não foi atestado em seus produtos termicamente processados, especialmente após a extrusão. 


\section{OBJETIVO}

\subsection{Objetivo geral}

Verificar a via de ação hipocolesterolêmica dos hidrolisados do feijão caupi e o efeito do processamento térmico nesta propriedade.

\subsection{Objetivos específicos}

$\checkmark$ Modelar o processo de extrusão para o feijão caupi de forma a obter um produto com maior expansão;

$\checkmark$ Determinar a capacidade dos hidrolisados do feijão caupi (cru, cozido e extrusado) de inibir a ação da enzima HMGR e a solubilização micelar do colesterol após digestão in vitro;

Comparar a capacidade dos hidrolisados de inibir a ação da enzima HMGR e a solubilização micelar do colesterol, de acordo com os diferentes tratamentos térmicos. 


\section{MATERIAL E MÉTODOS}

\subsection{Obtenção da farinha do feijao caupi cru}

O feijão caupi (Vigna unguiculata L. Walp) cultivar BRS-Milênio, foi fornecido pela EMBRAPA transferência de tecnologia escritório de Petrolina, Pernambuco. Os grãos de feijão foram triturados e tamisados (peneira de 0,42 mm), gerando a farinha de feijão cru (Fcru) que também foi utilizada como matéria-prima para a extrusão.

\subsection{Obtenção da farinha de feijão caupi cozido}

Os grãos de feijão caupi cru foram levados à cocção em autoclave (SANYO modelo MLS-3751L), simulando a condição de processamento e de consumo mais frequente desse tipo de feijão. Os grãos foram imersos em água na proporção de 1:2 $\mathrm{m} / \mathrm{v}$ e deixados em repouso por 12 horas em geladeira para hidratação. Após este período, foi levado a cocção em sacos autoclaváveis com a mesma água do remolho a $115{ }^{\circ} \mathrm{C}$ por 30 minutos. Juntamente com o caldo, o feijão foi congelado, liofilizado, triturado e tamisado (peneira de $0,42 \mathrm{~mm}$ ) sendo denominado de farinha de feijão cozido (Fcoz).

\subsection{Modelagem do processo de extrusão e obtenção da farinha de feijão caupi extrusado}

Parte da farinha de feijão caupi cru foi empregada na produção do extrusado. Para a extrusão foi utilizada extrusora de rosca única com capacidade de produção semi-industrial (modelo ELM20-MIOTTO, São Bernardo, Brasil). O equipamento apresenta rosca única, sistema composto por 3 zonas aquecidas através de resistências elétricas independentes. O controle da temperatura é feito por termopares, um sistema de refrigeração a água por válvulas solenoides na primeira e segunda zona e a ar na terceira zona (saída do material). A alimentação da extrusora é conduzida por um silo com a dosagem manual. Acoplado à extrusora há 
um painel informatizado para controle das variáveis: temperatura, rotação da rosca e velocidade de alimentação.

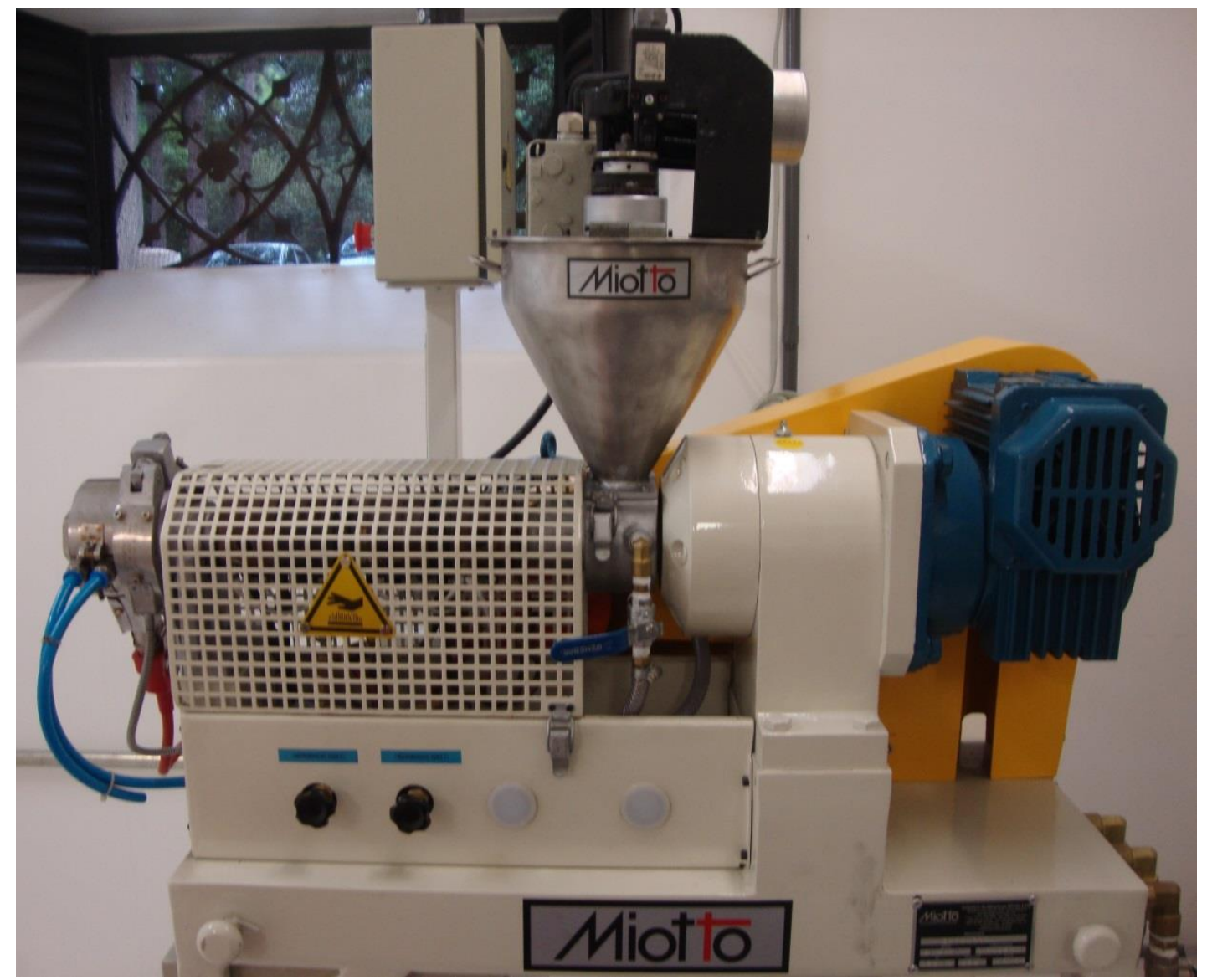

Figura 2 - Extrusora de laboratório ELM20-MIOTTO.

O processo de extrusão foi modelado de forma similar ao realizado para várias outras matérias primas com teor significativo de proteínas que tiveram sua extrusão realizada no Laboratório de Propriedades Funcionais de Alimentos da FSP/USP (BATISTUTI, BARROS e AREAS, 1991; CHAVEZ-JAUREGUI, SILVA e AREAS, 2000; CARDOSO SANTIAGO et al., 2001; CONTI E SILVA, DA CRUZ e GOMES AREAS, 2010; BOMBO TREVISAN e GOMES AREAS, 2012).

Inicialmente experimentos exploratórios foram conduzidos estabelecendo-se como variáveis independentes do processo: umidade da farinha de feijão, temperatura da região central ( $2^{a}$ zona) e velocidade de rotação da rosca para determinar as condições de operação do equipamento. As demais condições de extrusão foram fixas durante todo o experimento:

- Temperatura na zona 1:60 ํㅜ;

- Rosca com taxa de compressão 1:3; 
- Diâmetro da matriz: 3,0 mm;

Para ajuste de umidade da farinha, foi adicionada a quantidade de água necessária de acordo com os pontos determinados pelo delineamento experimental, seguido de homogeneização manual e estocagem em sacos plásticos lacrados sob refrigeração, por 12 horas, para equilíbrio da umidade desejada.

A razão de expansão radial $(R E)$ foi obtida logo após a extrusão e calculada através do quociente entre o diâmetro dos extrusados e o diâmetro do orifício de saída da extrusora, conforme a metodologia proposta por Faubion e Hoseney (1982). Para a medida do diâmetro dos extrusados foi utilizado um paquímetro digital (Marca Mitutoyo) e o valor considerado foi obtido pela média aritmética de 10 medidas aleatórias. A razão de expansão do extrusado foi avaliada como variável resposta indicadora da qualidade de sua texturização. É uma variável ideal para estudo sistemático de otimização, pois é obtida rapidamente, com medidas simples e correlaciona-se com variáveis de textura mais complexas, obtidas pela Análise do Perfil de Textura Instrumental (BATISTUTI, BARROS e AREAS, 1991). Para descrição do processo foi empregada uma equação polinomial, obtida através de análise de regressão múltipla do efeito das variáveis independentes na expansão radial do extrusado.

$y=b_{0}+b_{1 X_{1}}+b_{2 X_{2}}+b_{3 X_{\mathrm{g}}}+b_{12 X_{1} X_{2}}+b_{13 X_{1} X_{\mathrm{g}}}+b_{23 X_{2} X_{\mathrm{g}}}+E_{0}$

onde:

$y=$ resposta (para a modelagem - razão de expansão radial)

$x_{1}, x_{2}, x_{3}$-variáveis independentes;

$b_{0}, b_{1}, b_{2} . ., b_{11}, b_{22}, \ldots, b_{12}, b_{13} \ldots-$ coeficientes;

$E_{0}$ - erro com distribuição normal e média 0 .

Este modelo avalia as contribuições lineares e interações de cada variável independente na variável resposta visando compreender os efeitos das variáveis independentes na resposta. A análise estatística para decisão da escolha dos coeficientes significativos do modelo seguiu-se o padrão empregado na Metodologia de Superfície de Resposta, visando obter o melhor ajuste (BOX e DRAPER, 1987; BARRROS NETO, SCARMINIO e BRUNS, 2003). Para todos os delineamentos os experimentos foram executados em ordem crescente de temperatura, para maior 
estabilidade do equipamento, sendo sorteadas as condições de umidade e rotação de rosca a fim de se obter uma ordem aleatorizada.

Os experimentos para a modelagem foram conduzidos segundo um planejamento fatorial fracionado em dois níveis $\left(2^{3}\right)$ com repetição do ponto central (Tabela 1).

Tabela 1 - Matriz do planejamento fatorial $2^{3}$ com repetição do ponto central.

\begin{tabular}{|c|c|c|c|c|c|c|}
\hline \multirow[b]{2}{*}{ ENSAIOS } & \multicolumn{3}{|c|}{$\begin{array}{c}\text { Variáveis } \\
\text { codificadas }\end{array}$} & \multicolumn{3}{|c|}{ Variáveis decodificadas } \\
\hline & $\mathbf{x}_{1}$ & $\mathbf{X}_{2}$ & $\mathbf{x}_{3}$ & $\begin{array}{c}\% \\
\text { Umidade } \\
\left(\mathbf{x}_{1}\right)\end{array}$ & $\begin{array}{c}\text { rpm } \\
\text { V. rosca } \\
\left(x_{2}\right)\end{array}$ & $\begin{array}{c}{ }^{\circ} \mathbf{C} \\
\text { Temperatura } \\
\left(\mathbf{x}_{3}\right)\end{array}$ \\
\hline 1 & -1 & -1 & -1 & 18 & 100 & 110 \\
\hline 2 & +1 & -1 & -1 & 28 & 100 & 110 \\
\hline 3 & -1 & +1 & -1 & 18 & 200 & 110 \\
\hline 4 & +1 & +1 & -1 & 28 & 200 & 110 \\
\hline 5 & -1 & -1 & +1 & 18 & 100 & 190 \\
\hline 6 & +1 & -1 & +1 & 28 & 100 & 190 \\
\hline 7 & -1 & +1 & +1 & 18 & 200 & 190 \\
\hline 8 & +1 & +1 & +1 & 28 & 200 & 190 \\
\hline 9 & 0 & 0 & 0 & 23 & 150 & 150 \\
\hline 10 & 0 & 0 & 0 & 23 & 150 & 150 \\
\hline 11 & 0 & 0 & 0 & 23 & 150 & 150 \\
\hline
\end{tabular}

Após avaliar o modelo foi selecionada a melhor condição a ser utilizada para obtenção do extrusado.

Os extrusados foram triturados, sendo denominados de farinha de feijão extrusado (Fex). 


\subsection{Obtenção dos isolados proteicos a partir das farinhas}

As Fcru e Fcoz foram desengorduradas com hexano na proporção 1:6 m/v, secas em estufa a $60^{\circ} \mathrm{C}$ e tamisadas (peneira de $0,42 \mathrm{~mm}$ ).

$\mathrm{O}$ isolamento proteico utilizado foi baseado na metodologia sugerida por Wright e Bumstead (1984), de forma similar ao realizado no feijão caupi em trabalhos anteriores realizados no Laboratório de Propriedades Funcionais de Alimentos da FSP/USP (FROTA et al., 2008; FROTA, 2011) por precipitação isoelétrica como ilustrado na Figura 2. 


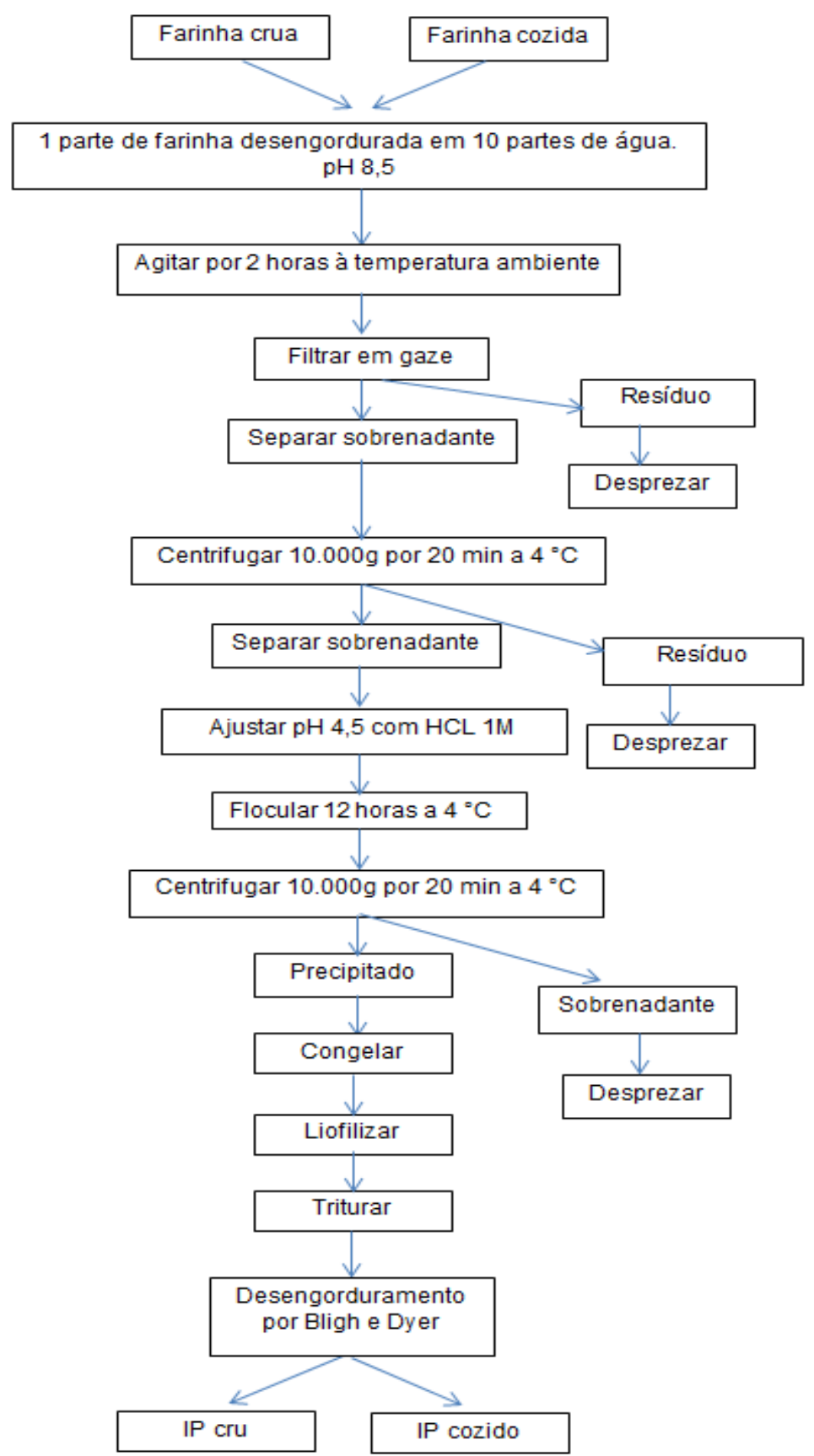

Figura 3 - Fluxograma do isolamento proteico das farinhas de feijão caupi crua e cozida.

Após desengorduradas, o pH das suspensões de 10\% das farinhas em água foi ajustado com $\mathrm{NaOH} 1 \mathrm{M}$ e deixadas por 2 horas sob agitação horizontal em $\mathrm{pH}$ 8,5. Posteriormente, as suspensões foram filtradas com auxílio de gaze e o resíduo descartado. Em seguida, os filtrados foram centrifugados e os precipitados foram removidos. Os sobrenadantes foram armazenados sob refrigeração $\left(4^{\circ} \mathrm{C}\right)$ durante $12 \mathrm{~h}$ em pH 4,5, por adição de $\mathrm{HCl} 1 \mathrm{M}$, para floculação. Após esta etapa, as 
misturas foram novamente centrifugadas. As frações insolúveis (precipitado) representando os isolados proteicos de caupi foram coletadas e posteriormente liofilizadas, trituradas em moinho.

Com o objetivo de produzir isolados de maior pureza, os precipitados foram novamente desengordurados pelo método de Bligh e Dyer (1959), secos, tamisados (peneira de 0,42 mm) e acondicionados em sacos de polietileno, selados e armazenados em refrigeração até a hidrólise enzimática, gerando o IPcru (isolado proteico da Fcru) e IPcoz (isolado proteico da Fcoz)

\subsection{Composição centesimal e fibras}

Nas farinhas Fcru, Fcoz e Fex, foram determinados os teores de umidade, proteínas, lipídeos, cinzas, fibras solúvel e insolúvel segundo a AOAC (2010), métodos 950.46, 923.04, 960.52, 920.39 e 985.29, respectivamente. Para o cálculo da proteína, empregou-se o fator de conversão 6,25. Os carboidratos totais foram calculados por diferença. $O$ valor energético foi calculado utilizando os fatores de conversão de Atwater, sendo $4 \mathrm{kcal} . \mathrm{g}^{-1}$ para proteínas e carboidratos e $9 \mathrm{kcal} . \mathrm{g}^{-1}$ para lipídeos.

Nos isolados proteicos (IPcru e IPcoz) foram realizadas as análises de umidade e proteína de acordo com metodologia da AOAC (2010), 950.46 e 923.03 respectivamente. Os lipídeos foram determinados pelo método de Bligh e Dyer (1959). 


\subsection{Perfil de ácidos graxos}

Os ácidos graxos das farinhas Fcru, Fcoz e Fex foram determinados como ésteres metílicos de ácidos graxos por meio de cromatografia gasosa. Os lipídeos das farinhas foram extraídos segundo o método de Bligh e Dyer (1959) e uma alíquota contendo aproximadamente $100 \mathrm{mg}$ de lipídeos foi submetida à saponificação com $\mathrm{NaOH} 0,5 \mathrm{~N}$ em metanol. Em seguida, foram esterificadas com BF3 a $80^{\circ} \mathrm{C}$ durante 5 minutos, resfriada e extraída com hexano (MORRISON; SMITH, 1964).

Para identificar os ácidos graxos, foi injetado um padrão externo contendo ésteres metílicos de ácidos graxos (37 FAME mix 47885, Supelco). O cromatógrafo gasoso (Shimadzu GC-2010, Tokyo, Japan) foi equipado com uma coluna capilar de $100 \mathrm{~m}$ (Supelco SP-2560) com diâmetro interno de 0,25 mm e espessura do filme $0,20 \mu \mathrm{m}$. $\mathrm{O}$ forno foi operado a uma temperatura inicial de $140^{\circ} \mathrm{C}$ durante 5 minutos e programada uma rampa de temperatura $4^{\circ} \mathrm{C} \cdot \mathrm{min}^{-1}$ até atingir $230{ }^{\circ} \mathrm{C}$ e a $5^{\circ} \mathrm{C} \cdot \mathrm{min}^{-1}$ até atingir $240^{\circ} \mathrm{C}$ mantendo por 11 minutos. A temperatura do injetor foi configurada em $250^{\circ} \mathrm{C}$ e a temperatura do detector em $260^{\circ} \mathrm{C}$. O hidrogênio foi o gás de arraste utilizado, a um fluxo de $1 \mathrm{~mL} \cdot \mathrm{min}^{-1}$ e razão de split de 1:30. O volume de um $1 \mu \mathrm{L}$ de amostra ou padrão foi injetado. Os resultados foram expressos em $\mathrm{mg}$ de ácidos graxos/100g de amostra.

\subsection{Hidrólise in vitro do IPcru, IPcoz e da Fex}

A hidrólise dos IPcru, IPcoz e da Fex objetivou simular a digestão gástrica e intestinal humana, segundo Megías et al. (2009).

Em solução de $2 \%$ de proteína em $\mathrm{NaCl} 30 \mathrm{mM}$ a $37^{\circ} \mathrm{C}, \mathrm{pH}=2$, adicionou-se pepsina, relação enzima/substrato $1: 1000 \mathrm{~m} / \mathrm{m}$. A mistura foi deixada em incubação por 2 horas em banho-maria com agitação constante (modelo SW22 - JULABO). Após acertar o pH para $7 \mathrm{com} \mathrm{NaOH} 1 \mathrm{~N}$, houve subsequente adição de pancreatina 
(P7545 - SIGMA), relação enzima/substrato 1:1000 m/m, por mais 2 horas, totalizando 4 horas de digestão enzimática para se obter um hidrolisado com grau de hidrólise rica em peptídeos (SILVESTRE, HAMON e YVON, 1994; BIASUTTI et al., 2008). A reação foi interrompida com aquecimento de $80^{\circ} \mathrm{C}$ por 20 minutos e os hidrolisados submetidos à centrifugação a $9880 \times g$ por 20 minutos separando os sobrenadantes.

Para isolar peptídeos de baixo peso molecular, o sobrenadante foi passado através de uma membrana de ultrafiltração por centrifugação (7000 g/40 min) em dispositivos Millipore AMICON de $3 \mathrm{kDa}$ e utilizado nos ensaios subsequentes, gerando os hidrolisados do IPcru, hidrolisados do IPcoz e hidrolisados da Fex (Figura 4). Cada um dos hidrolisados foram submetidos à quantificação de proteína solúvel pelo método de Lowry (Lowry, et al., 1951).

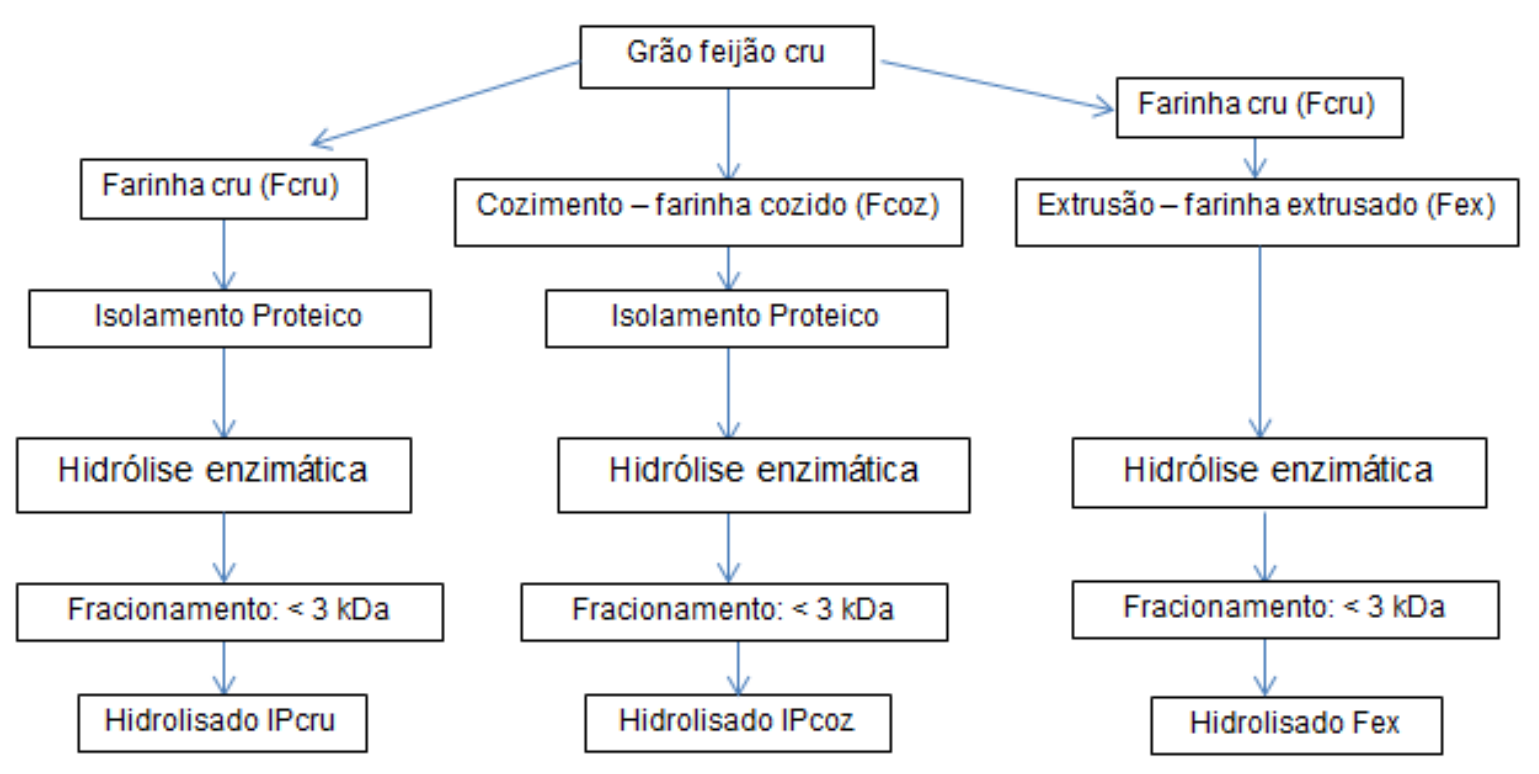

Figura 4 - Fluxograma das etapas para obtenção dos hidrolisados.

\subsection{Determinação do grau de hidrólise}

O grau de hidrólise foi quantificado como a solubilidade da proteína em ácido tricloroacético (TCA) de acordo com Hoyle e Merritt (1994).

. Possuindo uma boa correlação com valores obtidos in vivo (SAUNDERS et al 1973), este método de determinação do grau de hidrólise baseia-se no uso do TCA 
para precipitar a proteína não hidrolisada que pode estar presente, admitindo que o nitrogênio quantificado no sobrenadante seja proveniente de aminoácidos e pequenos peptídeos (RUTHERFURD, 2010).

Uma alíquota de $10 \mathrm{~mL}$ de cada hidrolisado foi adicionada em $10 \%$ de TCA para solubilização e após 15 minutos em repouso, as replicatas foram centrifugadas a 10000 x g por $15 \mathrm{~min}$. O teor proteico foi analisando no sobrenadante determinado pelo método de determinação de proteínas pelo método de Kjeldhal 923.04 da AOAC (2010).

As proteínas solúveis em TCA dos hidrolisados, foram relacionadas de forma percentual às quantidades totais de proteína presente nos isolados proteicos (IPcru e IPcoz) ou na farinha (Fex), calculado de acordo com a seguinte equação:

$$
\% \mathrm{GH}=\frac{\text { P. hidrolisados }}{\text { Proteína total }} \times 100
$$

Onde:

\%GH: Percentual de grau de hidrólise

P. hidrolisados: quantidade de proteínas solúveis em TCA dos hidrolisados;

Proteína total: quantidade de proteínas presentes no isolado proteico (IPcru e IPcoz) ou da farinha (Fex).

\subsection{Perfis dos hidrolisados em cromatografia líquida de alta eficiência (CLAE)}

Para o controle positivo da presença de peptídeos, os hidrolisados oriundos dos dispositivos de ultrafiltração tiveram suas ligações peptídicas detectadas a $220 \mathrm{~nm}$ com auxílio de um cromatógrafo líquido (Shimadzu - Japão) com controlador LC10AT, bomba DGU-14A acoplada a injetor manual Rheodyne e detector UV/vis com arranjo de diodos SPD-M10A VP. O software utilizado foi o Class VP. 
A separação cromatográfica foi realizada em coluna de fase reversa $\mathrm{C} 18$ Atlantis de $250 \times 0,46 \mathrm{~mm}$ e partículas de $5 \mu \mathrm{m}$ (Waters - Irlanda). O volume de injeção foi de $20 \mu \mathrm{L}$. A fase móvel utilizada foi: Solvente A 0,045 \% de ácido trifluoro acético (TFA) em água milli $Q$; Solvente B $0,036 \%$ de TFA em acetonitrila. As amostras foram eluídas em gradiente linear de 5 a $95 \%$ de tampão B em 55 minutos, mais 5 minutos para voltar a concentração inicial e 10 minutos para estabilização da coluna totalizando 70 minutos de corrida. O fluxo foi de $1 \mathrm{~mL} \cdot \mathrm{min}^{-1}$. $O$ gradiente selecionado foi baseado na polaridade e solubilidade dos diferentes peptídeos (SWERGOLD e RUBIN, 1983; VIJAYALAKSHMI, LEMIEUX e AMIOT, 1986).

\subsection{Ensaio de inibição da enzima HMGR in vitro}

O kit de ensaio da enzima HMGR da Sigma-Aldrich (kit CS 1090, St. Louis, $M O$, EUA) foi utilizado de acordo com as recomendações do fabricante para confirmar o efeito biológico dos hidrolisados na via hepática de biossíntese do colesterol.

O ensaio baseia-se na leitura espectrofotométrica do decréscimo da absorbância a $340 \mathrm{~nm}$, representando a oxidação da Nicotinamida adenina dinucleotídeo fosfato reduzido (NADPH) pela subunidade catalítica de HMGR, na presença do substrato HMG-CoA, de acordo com a reação abaixo:

$$
\mathrm{HMG}-\mathrm{CoA}+2 \mathrm{NADPH}+2 \mathrm{H}^{+} \longrightarrow \text { mevalonato }+2 \mathrm{NADP}^{+}+\mathrm{CoA}-\mathrm{SH}
$$

A pravastatina $(250 \mathrm{nM})$ foi utilizada como controle positivo, uma vez que inibe a ação catalítica da HMGR.

Alíquotas contendo $4 \mu \mathrm{L}$ de NADPH (concentração final de $400 \mu \mathrm{M}$ ) e $12 \mu \mathrm{L}$ de substrato HMG-CoA (concentração final de $0,3 \mathrm{mg} \cdot \mathrm{mL}^{-1}$ ) foram pipetadas em placas

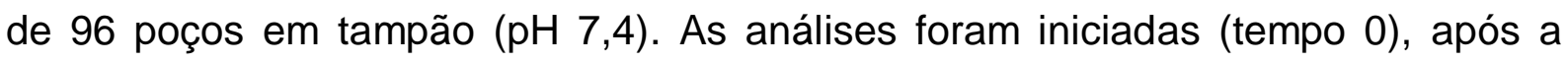
adição de $2 \mu \mathrm{L}$ da HMGR $(0,50-0,70 \mathrm{mg} / \mathrm{mL}$ de proteína) em um volume final de $0,2 \mathrm{~mL}$ por poço. A mistura foi incubada a $37^{\circ} \mathrm{C}$ na ausência de inibidores (controle), 
na presença da alíquota de $1 \mu \mathrm{L}$ de pravastatina e em várias concentrações de proteína de cada hidrolisado $(20,40,50,80 \mu \mathrm{g} / \mathrm{mL})$, separadamente e em triplicata. As quantidades de NADPH consumidas foram monitorizados a cada 20 segundos durante 10 minutos em leitor de placas SpectraMax M5 (Molecular Devices, Sunnyvale, CA, EUA). Os resultados foram calculados como $\mu$ mol de NADPH oxidado/min/mg de proteína, segundo equação abaixo:

$$
\text { Unidades } / \mathrm{mgP}=\frac{\frac{\Delta \text { Abs amostra }}{\min }-\frac{\Delta \text { Abs branco }}{\min }}{12,44 \times 0,006 \times 0,6 \times 0,55} \times 0,2
$$

Levando em consideração a reação na ausência de inibidores

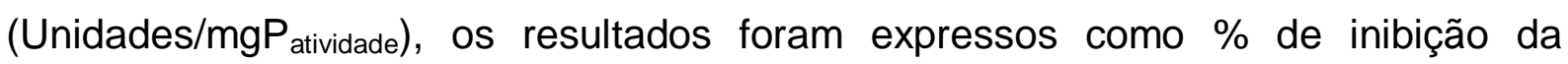
atividade da enzima na presença do medicamento ou dos hidrolisados (Unidades $/ \mathrm{mgP}_{\text {amostra }}$ ).

Capacidade de inibição(\%) $=\frac{\left(\text { Unidades } / \mathrm{mgP}_{\text {atividade }}-\mathrm{Unidades} / \mathrm{mgP}_{\text {amostra }}\right)}{\text { Unidades } / \mathrm{mgP}_{\text {atividade }}} \times 100$

\subsection{Ensaio da inibição da solubilização micelar do colesterol in vitro}

Soluções concentradas de fosfatidilcolina e sais biliares são comumente utilizadas como sistemas modelo de bílis humana. A função detergente dos sais biliares solubiliza os fosfolipídeos insolúveis em pequenas micelas mistas e também possui capacidade para solubilizar pequenas quantidades de colesterol em água (MARRINK e MARK, 2002).

As micelas mistas foram preparadas baseando-se nos métodos de Jesh e Carr (2006) e Zhang et al. (2012). A mistura lipídica (concentrações finais: 0,5 mM de colesterol, $1 \mathrm{mM}$ de ácido linoléico e 2,4 $\mathrm{mM}$ de fosfatidilcolina) foi combinada 
com tampão fosfato de sódio $15 \mathrm{mM}$ contendo 6,6 $\mathrm{mM}$ de taurocolato e $132 \mathrm{mM}$ de $\mathrm{NaCl}$ em $\mathrm{pH} 7,4$. As suspensões foram sonicadas num banho com gelo, usando um sonicador Transsonic Digital S (Elma) a $100 \%$ da potência máxima (140 W) por $15 \mathrm{~min}$.

Imediatamente após sonicar, foi adicionado $1 \mathrm{mg} / \mathrm{mL}$ de proteína de cada hidrolisado. As soluções foram novamente sonicadas durante 1 min e incubadas por 1 hora à $37^{\circ} \mathrm{C}$. As suspensões na presença e na ausência dos hidrolisados foram centrifugadas a $1000 \times \mathrm{g}$ por $10 \mathrm{~min}$ para separar o colesterol insolúvel. Os sobrenadantes foram filtrados em filtros Millex-GP 0,20 $\mu \mathrm{m}$ (Millipore, Bedford, MA, EUA)

Coletaram-se $50 \mu \mathrm{L}$ do filtrado para que as concentrações de colesterol fossem determinadas, utilizando o Kit de ensaio de colesterol do Amplex ${ }^{\circledR}$ red (invitrogen, Paisley, Reino Unido). A determinação foi realizada por meio de fluorescência (excitação em 555 nm e emissão da detecção em 590 nm) com auxílio de um leitor de placas SpectraMax M5 (molecular devices, Sunnyvale, CA, EUA) de acordo com instruções do fabricante. As concentrações de colesterol foram determinadas a partir da curva padrão de calibração de colesterol. A capacidade de inibição foi calculada utilizando a seguinte equação:

$$
\text { Capacidade de inibição }(\%)=\left[\frac{\mathrm{C}_{0}-\mathrm{C}_{\mathrm{S}}}{\mathrm{C}_{0}}\right] \times 100
$$

Onde: $C_{0}$ é a concentração de colesterol das micelas originais sem amostras e $C_{S}$ é a concentração de colesterol das micelas com hidrolisados.

\subsection{Análise dos resultados}

Os resultados foram expressos como média e desvio padrão de três determinações. O software Statistica 11 foi utilizado na modelagem do processo de extrusão e nas demais análises estatísticas. Os dados obtidos foram submetidos à análise de variância (ANOVA) e quando a interação foi significativa, o teste de comparação múltipla de Tukey foi adotado como teste post hoc para as diferenças 
entre as médias. O teste t-Student também foi utilizado de acordo com a necessidade. Adotou-se o nível de significância de $\mathrm{p}<0,05$ para todas as análises.

\section{RESULTADOS E DISCUSSÃO}

\subsection{Testes exploratórios e modelagem do processo de extrusão}

Os testes iniciais conduzidos para determinar as faixas de variação para o funcionamento da extrusora demonstraram que umidades superiores a $30 \%$ prejudicam a homogeneidade da amostra inviabilizando o processo de extrusão. Isso ocorre devido à obstrução do canhão e trava do rosca pela massa alimentícia. Além disso, foi observado que temperaturas superiores a $190{ }^{\circ} \mathrm{C}$ produzem um extrusado queimado e sem expansão. A partir do exposto foi planejado um delineamento $2^{3}$ com repetição do ponto central.

Após avaliar as respostas obtidas, não houve necessidade de uma nova modelagem, uma vez que, a análise de variância não apontou que um modelo quadrático poderia explicar o processo (Tabela 2). Os testes exploratórios mostraram que em regiões diferentes a extrusão não é viável.

Tabela 2 - Análise de variância para o ajuste do modelo linear aos dados da razão de expansão dos extrusados.

\begin{tabular}{lcccccc}
\hline $\begin{array}{l}\text { Fontes de } \\
\text { variação }\end{array}$ & $\begin{array}{c}\text { Soma dos } \\
\text { quadrados }\end{array}$ & $\begin{array}{c}\text { Graus de } \\
\text { liberdade }\end{array}$ & $\begin{array}{c}\text { Quadrado } \\
\text { médio }\end{array}$ & $\mathbf{F}_{\text {calc }}$ & $\mathbf{F}_{\text {teórico }}$ & $\mathbf{R}^{2}$ \\
\hline Regressão & 0,2291 & 3 & 0,0764 & 11,94 & 4,35 & $83,7 \%$ \\
Resíduos & 0,0447 & 7 & 0,0064 & & & \\
Falta de & 0,0422 & 5 & 0,008 & 6,67 & 19,30 & \\
$\begin{array}{l}\text { ajuste } \\
\text { Erro puro }\end{array}$ & 0,0025 & 2 & 0,0012 & & & \\
\hline Total & 0,2739 & 10 & & & & \\
\hline
\end{tabular}


A falta do ajuste é uma medida do fracasso de um modelo para representar os dados no domínio experimental em pontos que não foram incluídas na regressão ou variações nos modelos que não podem ser explicados pelo erro aleatório. $A$ adequação do modelo foi determinada através do teste de falta de ajuste, considerado suficiente para descrever a resposta (CHAKRABORTY et al., 2011).

A Tabela 3 apresenta o modelo de regressão utilizado neste estudo, ajustado para a expansão do feijão caupi. Considerando a variabilidade intrínseca do processo de extrusão e trabalhos anteriores como os de ASARE et al.( 2010a) que produziram blends de sorgo-amendoim-caupi modelados com $\mathrm{R}^{2}$ de $62,43 \%$, neste estudo obteve-se um coeficiente de correlação da regressão aceitável. .

Tabela 3 - Modelo de regressão para razão de expansão da farinha de feijão caupi*.
ATRIBUTO
EQUAÇÃO AJUSTADA
$\mathbf{R}^{2}(\%)$

$\begin{aligned} & \text { Razão de } \\ & \text { expansão }\end{aligned}$
Considerando $\mathrm{p}<0,05$.

Segundo os gráficos tridimensionais (Apêndice 1 e 2) a resposta expansão variou pouco. A interação das variáveis $\left(x_{1}, x_{2}, x_{3}\right)$ contribuiu de forma mais significativa para a expansão do que a temperatura de forma isolada (variável $x_{3}$ ), com efeito três vezes maior (Apêndice 3).

A variável umidade não contribuiu de forma significativa para expansão do extrusado neste estudo. $O$ aumento da umidade na farinha no início do processo tem um impacto negativo sobre a gelatinização do amido, reduzindo a expansão do produto. A umidade pode diminuir a temperatura da massa reduzindo 0 atrito entre a massa e o rosca/cilindro. (ASARE, EMMANUEL K. et al., 2010; ASARE, E. K. et al., 2010). O comportamento do processo em relação à velocidade de rotação da rosca foi o mesmo observado para a umidade: velocidades maiores ou menores não interferiram na expansão dos extrusados.

Lira Filho (2001) produziu extrusados de feijão caupi. Embora tenha usado uma faixa de variação maior para as variáveis independentes, também não observou a influência da velocidade da rosca. Por outro lado demonstrou uma pequena contribuição quadrática da temperatura (com ponto ótimo em $150^{\circ} \mathrm{C}$ ) e da umidade, porém, sem interação entre as variáveis. 
Com taxas de expansão de 2,46, o extrusado proposto nesse estudo está de acordo com as taxas de expansão radial do modelo de Lira Filho $(2,51)$.

Após ajustar matematicamente a produção de extrusados de feijão caupi foi escolhida a região de máxima temperatura para a produção dos extrusados baseado na análise dos Apêndices 1 e 2, onde se observa que a expansão aumenta nas regiões das altas temperaturas testadas. As condições utilizadas no ensaio 8 (Tabela 1) foram escolhidas para o estudo mais detalhado com relação a ação hipocolesterolêmica, por utilizar um elevado valor de temperatura e consequentemente gerar um extrusado com maior expansão, conforme Figura 5.

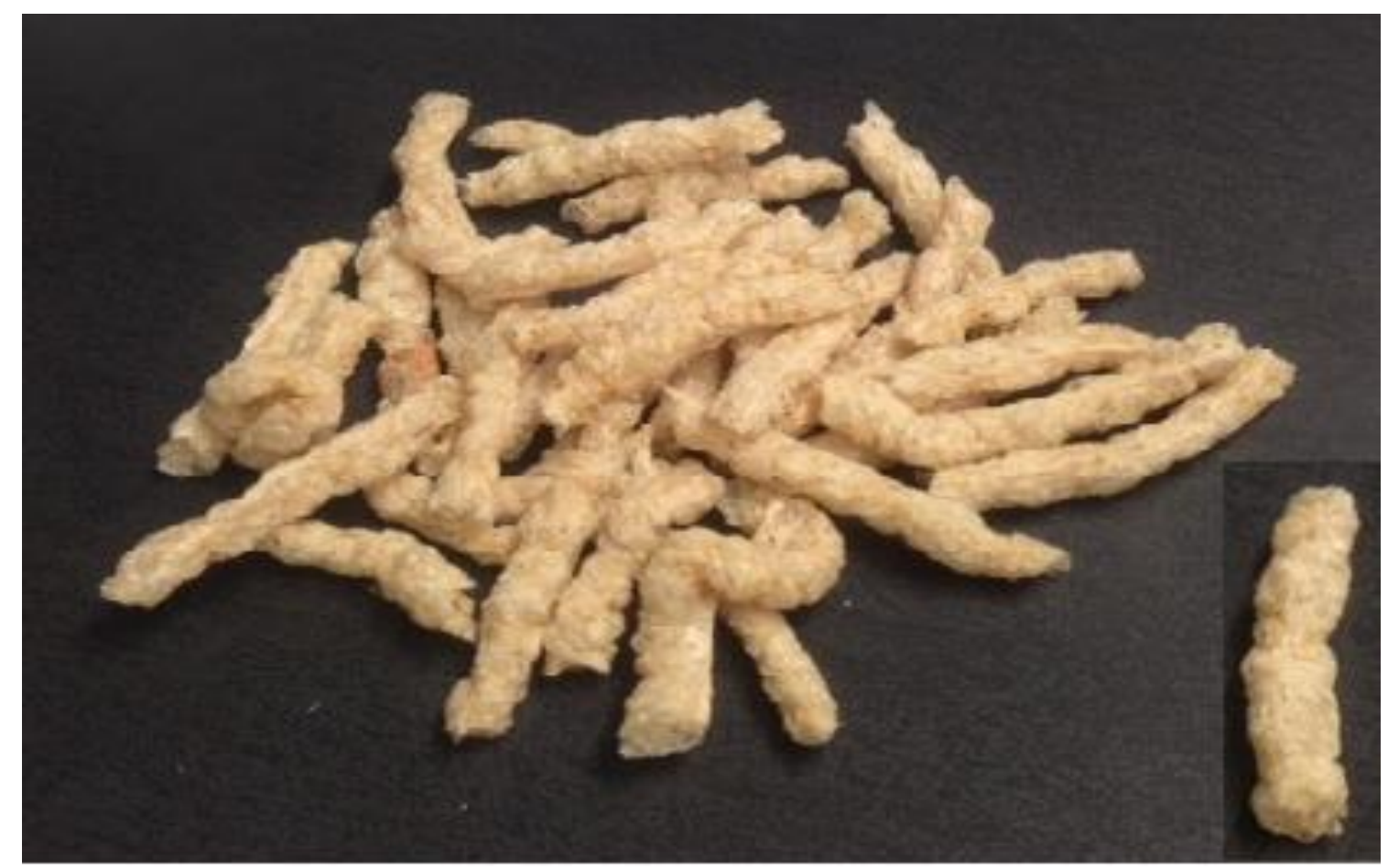

Figura 5 - Aparência final do feijão extrusado. 


\subsection{Caracterização das farinhas}

Os dados de composição centesimal das farinhas e dos isolados são exibidos na Tabela 4. A Fcru apresenta composição similar a estudos anteriores (FROTA, SOARES e AREAS, 2008; AVANZA et al., 2013).

Por ser hidratada antes do cozimento, obviamente a farinha cozida apresentou maior umidade.

O produto extrusado apresentou baixo teor de umidade, qualidade desejável para prolongar a sua vida útil. Em sistemas de alimentos secos, o conteúdo de entre $6 \%$ e $10 \%$ de umidade combinados com a atividade de água controlada é suficiente para prolongar a vida de prateleira de alimentos por mais tempo do que utilizando agentes químicos e microbiológicos, (ASARE et al., 2012).

Tabela 4 - Composição centesimal $\left(\mathrm{g} .100 \mathrm{~g}^{-1}\right)$ e valor energético (kJ. $\left.100 \mathrm{~g}^{-1}\right)$ das farinhas Fcru, Fcox e Fex em base seca*.

\begin{tabular}{lccc}
\hline Componentes & \multicolumn{1}{c}{ Fcru } & Fcoz & Fex \\
\hline Umidade & $10,13 \pm 0,08$ & $75,12 \pm 7,52$ & $8,86 \pm 0,02$ \\
\hline Cinzas & $3,51 \pm 0,02$ & $3,04 \pm 0,01$ & $3,44 \pm 0,08$ \\
Proteínas & $23,72 \pm 1,44$ & $23,8 \pm 0,66$ & $25,61 \pm 0,63$ \\
Lipídeos & $1,70 \pm 0,11^{\mathrm{a}}$ & $2,29 \pm 0,09$ & $0,68 \pm 0,02^{\mathrm{b}}$ \\
Carboidratos & $71,05 \pm 1,57$ & $70,87 \pm 0,69$ & $70,27 \pm 0,69$ \\
Fibra total & $19,87 \pm 1,78^{\mathrm{a}}$ & $11,81 \pm 0,4^{\mathrm{b}}$ & $13,26 \pm 1,43^{\mathrm{b}}$ \\
\multicolumn{1}{c}{ Insolúvel } & $19,74 \pm 1,80^{\mathrm{a}}$ & $10,95 \pm 0,24^{\mathrm{b}}$ & $11,46 \pm 0,94^{\mathrm{b}}$ \\
\multicolumn{1}{c}{ Solúvel } & $0,13 \pm 0,07^{\mathrm{a}}$ & $0,98 \pm 0,38^{\mathrm{b}}$ & $1,4 \pm 0,33^{\mathrm{b}}$ \\
\hline $\begin{array}{l}\text { Valor calórico total } \\
\text { * Fcru - farinha integral; Fcoz }- \text { Farinha de originada de feijão cozido; Fex }- \text { Farinha originada do feijão } \\
\text { extrusado. Valores expressos em média } \pm \text { Desvio-padrão. Letras diferentes na mesma linha demonstram diferenças } \\
\text { estatísticas em relação a Fcru, teste t-Student ( } \mathrm{p}<0,05) .\end{array}$ &
\end{tabular}


Observou-se um decréscimo significativo na quantidade de fibras total e insolúvel após o cozimento por autoclave, porém, não afetou a quantidade dos outros constituintes, possivelmente por efeito da temperatura.

Assim como no estudo de Batista et al. (2010), a extrusão não gerou perdas significativas nos macroconstituintes, porém, a quantidade de fibras e lipídeos foi alterada. Destaca-se, que mesmo perdendo fibra total e insolúvel, a extrusão tornou as fibras insolúveis em solúveis ( $t=-6,22, p=0,02)$. A alta tensão estática, provida pela extrusora, quebrou as grandes cadeias moleculares da fração insolúvel em fragmentos menores (ZARZYCKI e RZEDZICKI 2009).

Redgwell et al. (2011) analisaram a composição de fibra vegetal isolada antes e após a extrusão, e a partir da análise das frações liberadas, chegaram à conclusão que as hemiceluloses e/ou a celulose da matéria prima foram clivadas em fragmentos menores. Isto foi confirmado pelos perfis de peso molecular dos polímeros solubilizados, 10 vezes menores que o seu tamanho original após a extrusão.

Houve diminuição significativa do teor de lipídeos após a extrusão, explicada por interações moleculares da fração lipídica com o amido que ocorrem no processo. Em virtude de sua estrutura tridimensional, o amido possui unidades repetidas de glicose orientadas em forma de hélice, com hidroxilas localizadas na parte externa. Como na parte interna existem apenas ligações carbono-hidrogênio, a parte interna da molécula possui caráter hidrofóbico. Essa região interna da hélice é responsável pela ligação de compostos apolares como os lipídeos (ARÊAS, 1996).

A análise realizada da composição de ácidos graxos nas farinhas mostrou diminuição das quantidades de ácidos graxos, devido à perda do total de lipídeos. A composição do perfil não se alterou com o tratamento térmico (Tabela 5). 
Tabela 5 - Perfil de ácidos graxos das farinhas Fcru, Fcoz e Fex (mg de ácidos graxos/100g de lipídeos totais).

\begin{tabular}{lccc}
\hline ÁCIDOS GRAXOS & Fcru$^{*}$ & Fcoz $^{*}$ & Fex $^{*}$ \\
\hline Palmítico (C16:0) & $332 \pm 0,49$ & $441 \pm 0,4$ & $126 \pm 0,49$ \\
Esteárico (C18:0) & $47 \pm 0,12$ & $58 \pm 0,05$ & $17 \pm 0,08$ \\
Oleico (C18:1n9cis) & $94 \pm 0,37$ & $120 \pm 0,23$ & $35 \pm 0,25$ \\
Linoleico (C18:2n) & $502 \pm 0,11$ & $688 \pm 0,25$ & $200 \pm 0,35$ \\
a- Linolênico (C18:3) & $317 \pm 1,09$ & $448 \pm 0,31$ & $138 \pm 0,98$ \\
Behênico (C22:0) & $45 \pm 0,31$ & $49 \pm 0,22$ & $14 \pm 0,07$ \\
Docosadienóico (C22:2) & $21 \pm 0,18$ & $22 \pm 0,06$ & $6 \pm 0,02$
\end{tabular}

*Fcru - farinha integral; Fcoz - Farinha de originada de feijão cozido; Fex - Farinha originada do feijão extrusado. Média \pm desvio-padrão.

Não houve mudanças, na proporção de saturados (29-31\%), monoinsaturados (6-7\%) e poliinsaturados (61-63\%) entre as farinhas (Figura 6). Em geral, o aquecimento de matérias primas alimentares, principalmente ricas em insaturações, pode promover reações de oxidação lipídica. Os processos térmicos são capazes de romper as membranas celulares, libertando pró-oxidantes e/ou levam ao aparecimento de pequenas quantidades de ácidos graxos trans por reações de isomerização (SATO e HEGARTY, 1971; BUDRYN et al., 2012; TSUZUKI, 2012). 


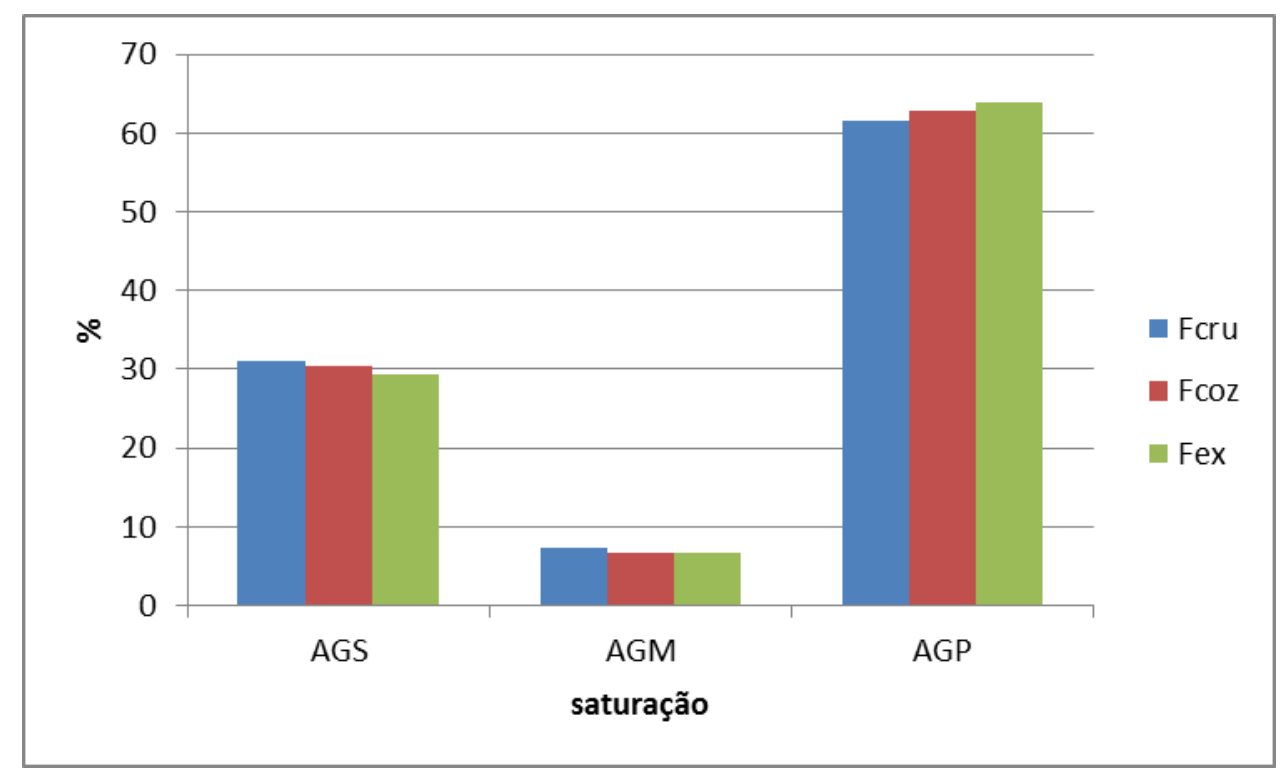

Figura 6 - Perfil de ácidos graxos das farinhas integral, cozida e extrusada de feijão caupi segundo grau de saturação (AGS - ácidos graxos saturados; AGM - ácidos graxos monoinsaturados; AGP - ácidos graxos poli-insaturados).

A isomerização de AGM (ácidos graxos monoinsaturados) e AGP (ácidos graxos poliinsaturados) que pode ocorrer no processamento de alimentos a altas temperaturas, não ocorreu devido às baixas temperaturas empregadas e ao curto tempo para o cozimento em autoclave, pois, é dependente do tempo de aquecimento, de temperaturas acima de $160{ }^{\circ} \mathrm{C}$ e a água presente durante $\mathrm{O}$ processo pode promover baixas temperaturas (PRZYBYLSKI e ALADEDUNYE 2012; TSUZUKI 2012).

\subsection{Caracterização dos isolados proteicos}

O cozimento em autoclave afetou a pureza do isolado proteico (IPcoz) (Tabela 6). Neste caso, a proteína sofreu modificações moleculares importantes que alteraram a solubilidade no meio como: pontes de hidrogênio, interações hidrofóbicas e pontes dissulfeto, tornando-a insolúvel. 
Tabela 6 - Composição centesimal $\left(\mathrm{g} .100 \mathrm{~g}^{-1}\right)$ dos isolados proteicos da Fcru e Fcoz em base seca.

\begin{tabular}{lcc}
\hline Componentes & Isolado proteico da Fcru* & Isolado proteico da Fcoz $^{*}$ \\
\hline Umidade & $10,44 \pm 0,58$ & $11,11 \pm 0,06$ \\
\hline Proteínas & $91,24 \pm 0,37$ & $74,33 \pm 0,38$ \\
Lipídeos & $0,48 \pm 0,2$ & $1,52 \pm 0,32$ \\
\hline
\end{tabular}

${ }^{\star}$ Fcru - farinha integral; Fcoz - Farinha de originada de feijão cozido

Carbonaro (1993) verificou o mesmo fenômeno em feijões do gênero Phaseolus. Uma redução de $40 \%$ na solubilidade foi determinada em feijões cozidos, e esta não se alterou mesmo em meio salino. Não houve alterações no ponto isoelétrico. O autor afirma que o cozimento altera a quantidade de resíduos básicos dentro da proteína, dificultando a solubilidade em água, e que somente em $\mathrm{pH}$ acima de 10 ou em meio a uma substância altamente dissociante como a ureia é que será possível obter uma maior pureza.

Neste estudo, a alta temperatura utilizada na extrusão pode ter gerado majoritariamente proteínas insolúveis por ligações dissulfeto e não-covalentes, similar a dados na literatura de soja e de outro tipo de feijão (PRUDENCIOFERREIRA e AREAS, 1993; ALONSO et al., 2000).

A precipitação isoelétrica utilizada para o isolamento proteico das farinhas é geralmente conduzida em meio a sistemas tamponados e em diferentes $\mathrm{pHs}$. $\mathrm{O}$ método parte do princípio de que o tampão e as cargas adicionadas podem solubilizar as proteínas livres, porém, este método não foi capaz de solubilizar as proteínas da Fex. Devido ao cross-linking entre proteínas e entre outros componentes dos alimentos, o rearranjo molecular torna-se imprevisível e dependente das variáveis empregadas no processamento. (ARÊAS, 1992). 


\subsection{Grau de hidrólise e perfis dos hidrolisados em cromatografia líquida de alta eficiência (CLAE)}

Os hidrolisados obtidos foram avaliados quanto ao seu grau de hidrólise, pois tal medida está fortemente correlacionada com a eficiência enzimática durante a hidrólise e com a digestão in vivo.

As diferenças no grau de hidrolise do IPcru $(23,3 \% \pm 6,0)$, IPcoz $(53,2 \% \pm$ $7,6)$ e da Fex $(40,8 \% \pm 1,3)$ demonstram que o processamento facilita 0 ataque das enzimas proteolíticas. A mudança conformacional da proteína após o processamento térmico pode ser o motivo dessas diferenças. Os estudos de Frota (2008) e de Avanza et al. (2013) avaliaram in vivo e in vitro a digestibilidade do feijão caupi. Estes últimos verificaram o aumento de digestibilidade em cerca de $85 \%$ após o cozimento de diversas variedades de feijão caupi

Valores elevados de grau de hidrólise não são desejados, pois, resulta em aminoácidos livres, devido a uma quebra completa da cadeia proteica. Valores baixos indica uma quebra insuficiente resultando em pequenas quantidades de peptídeos (XIA et al., 2012).

Os perfis dos hidrolisados monitorados por CLAE, podem ser observados nas Figuras 7, 8 e 9. É possível visualizar a existência de vários picos até aproximadamente os 20 minutos iniciais de corrida, confirmando a existência de peptídeos nos hidrolisados. Baseado no gradiente de eluição pode-se afirmar que os hidrolisados são em sua maioria polares em relação ao gradiente utilizado. 


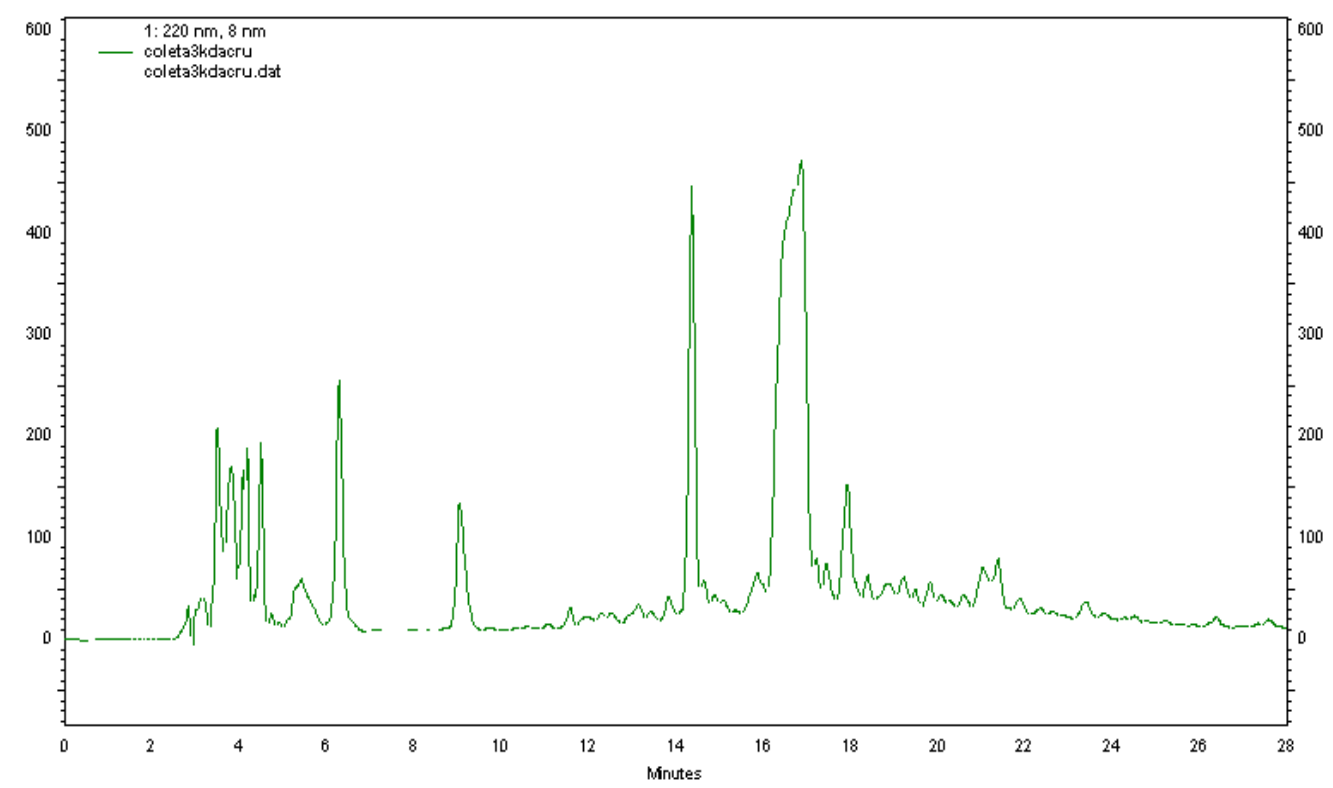

Figura 7 - Cromatogramas a $220 \mathrm{~nm}$ dos hidrolisados do IPcru.

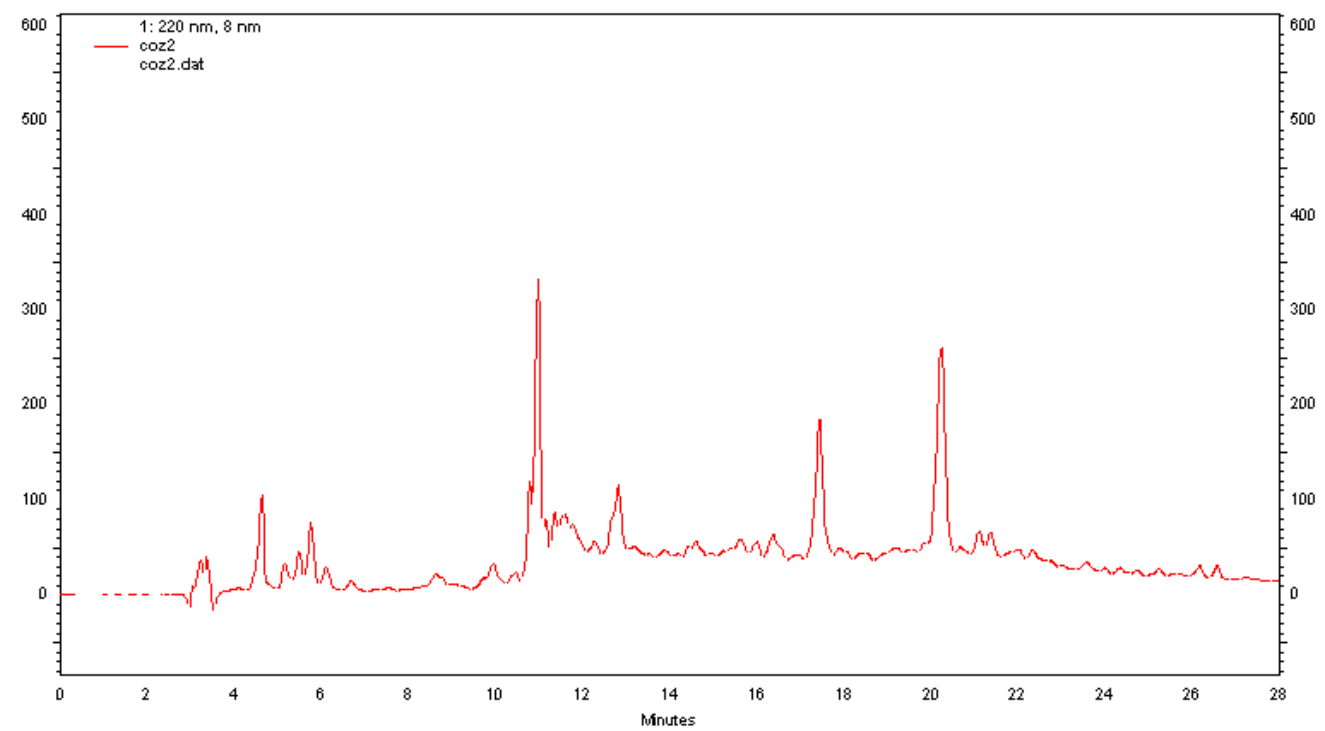

Figura 8 - Cromatogramas a $220 \mathrm{~nm}$ dos hidrolisados do IPcoz. 


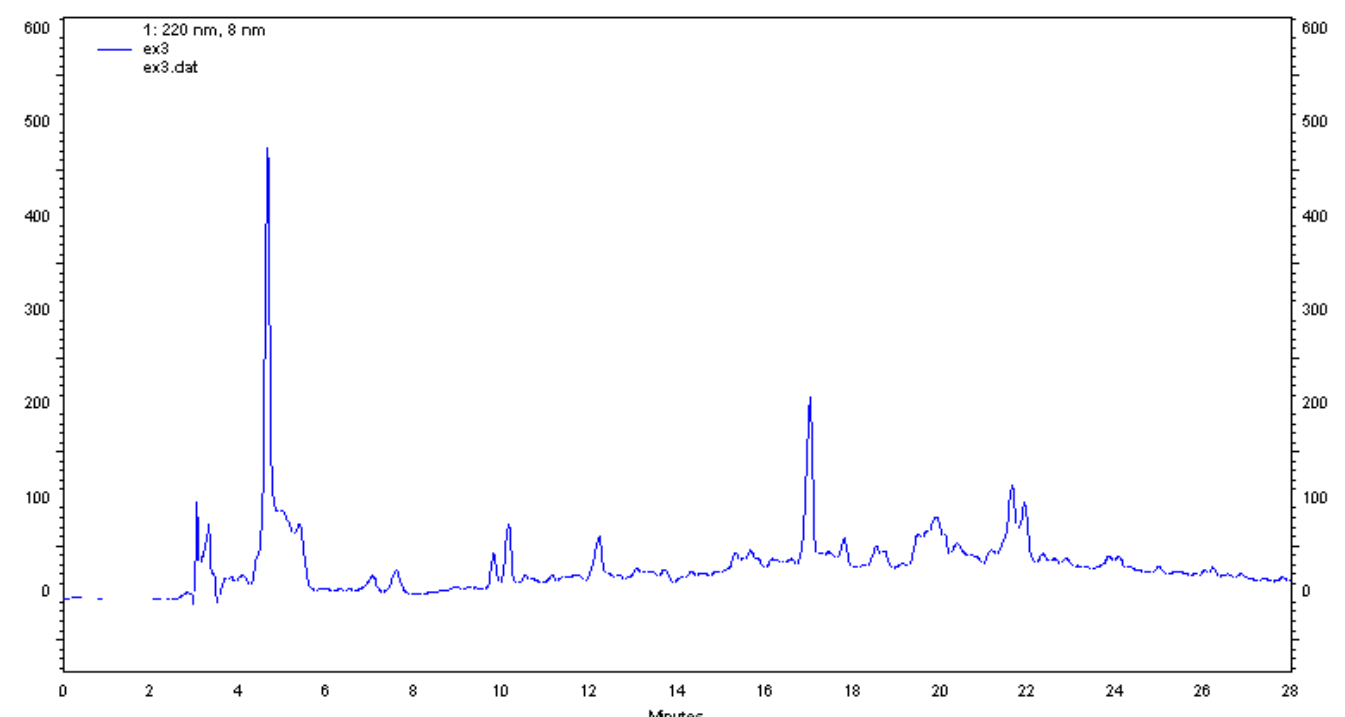

Figura 9 - Cromatogramas a $220 \mathrm{~nm}$ dos hidrolisados da Fex.

Os cromatogramas dos hidrolisados são diferentes entre si, apesar de possuírem polaridade semelhante em relação ao gradiente utilizado. $O$ motivo da pequena quantidade de picos na Figura 9 pode ser explicado pelo surgimento de novas ligações e interações hidrofóbicas e eletrostáticas, além do grau de hidrólise mais elevado, pois, segundo Vaz e Areas (2010), no processo de extrusão ocorre uma rápida reorganização de macromoléculas desnaturadas.

\subsection{Inibição da enzima HMGR por hidrolisados de feijão caupi}

\subsubsection{Hidrolisados provenientes dos isolados proteicos (IPcru e IPcoz)}

A Figura 10 abaixo reúne os resultados do percentual de inibição da enzima HMGR na presença de várias concentrações dos hidrolisados. A pravastatina (250 nM), utilizado como inibidor padrão da reação, obteve 98,4 \% de inibição. 


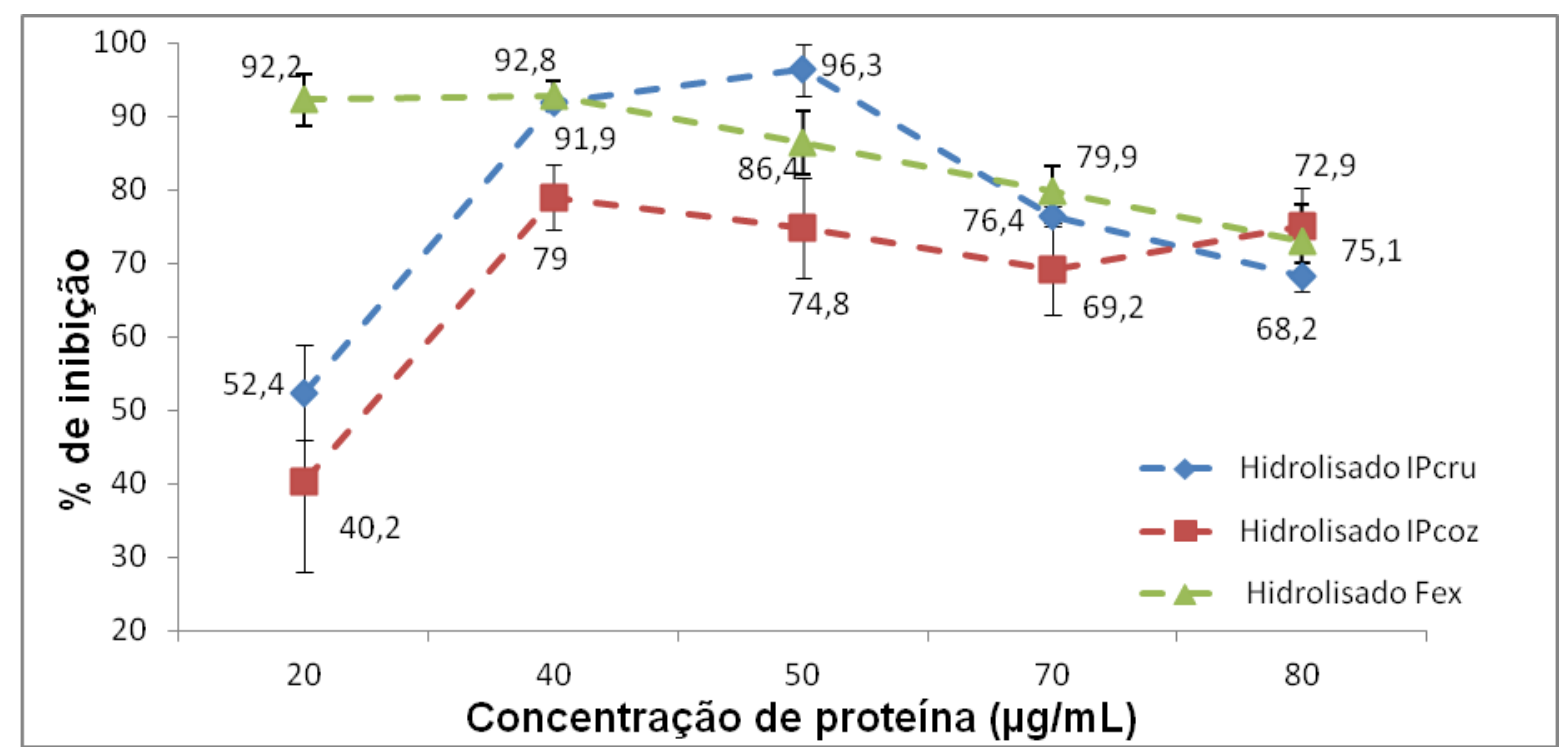

Figura 10 - Percentual de inibição da enzima HMGR na presença dos hidrolisados de feijão caupi segundo processamento. Média \pm Desvio-padrão.

Avaliando a Figura 10, os hidrolisados do IPcru e IPcoz apresentaram comportamentos semelhantes. Nota-se que a inibição da enzima em relação a quantidade de proteína indica uma saturação. Em doses mais elevadas de proteína (acima de $70 \mu \mathrm{g} / \mathrm{mL}$ ) a inibição apresentou-se estável, por volta dos $75 \%$.

A partir de $40 \mu \mathrm{g} / \mathrm{mL}$ de proteína, a capacidade inibitória dos hidrolisados IPcoz permanece em um intervalo, com valores em torno de 69-79 \% de inibição. A cocção em autoclave diminuiu a capacidade inibitória da proteína em relação ao hidrolisado IPcru no intervalo de 20 a $70 \mu \mathrm{g} / \mathrm{mL}$.

O efeito dos hidrolisados na inibição da HMGR podem ser explicado pela estrutura conformacional dos peptídeos. A presença constante de resíduo de prolina permite uma estrutura tridimensional devido ao ângulo de torção proporcionada por este aminoácido. Esta estrutura é semelhante a das estatinas, medicamentos utilizados para o tratamento médico da hipercolesterolemia (PAK, KOO, LEE, et al., 2005; PAK, KOO, KASYMOVA, et al., 2005; PAK et al., 2006).

Pak et al. (2005) monitoraram ligações peptídicas, isolaram e testaram picos de seus hidrolisados proteicos da fração 11S da soja e obtiveram percentuais de 37 a $75 \%$ de inibição dependente da fração testada. A concentração de $250 \mu \mathrm{M}$ de lovastatina, avaliado sob o mesmo protocolo (kit CS-1090 Sigma Aldrich) por Lachenmeier et al. (2012), foi capaz de inibir 60 \% da HMGR. O mesmo trabalho avaliou também a inibição enzimática de suplementos de levedura de arroz vermelho chinês, obtendo valores de inibição de $80 \%$ da HMGR, valores 
semelhantes aos obtidos neste estudo. Gholamhoseinian (2010) verificou que mais de 21 extratos metanólicos de fontes vegetais foram capazes de inibir entre 30-50 \% a atividade da HMGR. Portanto os isolados de feijão caupi mostraram-se mais eficientes na inibição da HMGR que extratos metanólicos de alguns vegetais (que inibiram de 30-50\%) e semelhantes à soja e a levedura de arroz que inibiram de 35-75 e $80 \%$ respectivamente.

\subsubsection{Hidrolisado proveniente da farinha de feijão extrusado (Fex)}

Em relação ao hidrolisado da Fex (Figura 10), à medida que se aumenta a quantidade de proteína a capacidade inibitória diminui. Baseado em pesquisas anteriores que confirmam a ação biológica das proteínas do caupi, é possível que os peptídeos existentes monitorados na cromatografia possam agir na inibição enzimática. No caso dos hidrolisados da farinha extrusada, podem existir outros componentes atuantes, dado a baixa pureza em proteína da amostra (FROTA et al., 2010).

Dados na literatura remetem o fato desses inibidores possuírem massa molecular de 8 a $30 \mathrm{kDa}$, por isso é improvável que inibidores de proteases tenham agido no centro catalítico da HMGR inibindo-a, já que são moléculas bem maiores do que as presentes nos hidrolisados utilizados nos ensaios (OLIVEIRA et al., 2002;PEREIRA, 2005; CHEVREUIL et al., 2009).

O tratamento térmico nos alimentos pode promover a ação hipocolesterolêmica, porém, não foram encontrados na literatura estudos que comprovem este efeito em extrusados. Do caldo do cozimento de atum foram isolados peptídeos capazes de auxiliar no tratamento de diabetes, demonstrando a influência positiva do processamento térmico de alimentos (HUANG et al., 2012). Cian et al. (2011) adicionaram hidrolisado de hemoglobina bovina em gritz de milho e obtiveram produtos extrusados com propriedade regulatória da pressão arterial e fonte antioxidante atestada in vitro.

No ensaio utilizado, os hidrolisados foram avaliados apenas localmente, sem levar em consideração: a bioacessibilidade nos órgão alvo in vivo, a interação com a flora bacteriana, a forma de absorção pelas células intestinais, a resistência às 
dipeptidases dentro do enterócito, a estabilidade no sangue e as proteases no próprio órgão alvo (SEGURA-CAMPOS et al. 2011).

\subsection{Inibição da solubilização micelar do colesterol in vitro}

\subsubsection{Hidrolisados provenientes dos isolados proteicos (IPcru e IPcoz)}

A Tabela 7 abaixo mostra os resultados da inibição da solubilidade do colesterol pelos hidrolisados.

Tabela 7 - Percentual de inibição da solubilização micelar do colesterol na presença de $1 \mathrm{mg} / \mathrm{mL}$ de proteína dos hidrolisados. Média \pm Desvio-padrão.

\begin{tabular}{ccc}
\hline Amostra & Concentração de colesterol $(\boldsymbol{\mu g} / \mathbf{m L})$ & Inibição $(\%)$ \\
\hline Controle & $4,62 \pm 0,5$ & 0 \\
Hidrolisado IPcru & $4,38 \pm 0,9$ & 5,2 \\
Hidrolisado Fex & $3,61 \pm 0,5$ & 21,9 \\
Hidrolisado IPcoz & $2,78 \pm 0,4$ & 39,8 \\
\hline
\end{tabular}

De acordo com a Tabela 7, os hidrolisados provenientes das matérias-primas processadas termicamente (hidrolisados do IPcoz e Fex) foram mais efetivas ao inibir a solubilidade do colesterol no meio. Os resultados demonstram que o efeito inibitório é dependente do processamento, que por sua vez, alterou o grau de hidrólise.

A insolubilização do colesterol, em relação à proteína é proporcionada pela presença de sequências peptídicas ricas em aminoácidos hidrofóbicos e neutros que competem com o colesterol por espaços micelares, reorganizando-se espontaneamente com os sais biliares. Quanto mais alto o grau de hidrólise da proteína, mais peptídeos e aminoácidos são liberados (MARRINK e MARK, 2002; MEGÍAS et al., 2009).

Estudos recentes com hidrolisados proteicos advogam que o colesterol contido nas micelas pode ser removido de seu interior por ação de peptídeos. 
Hidrolisados provenientes de arroz branco $(10 \mathrm{mg} / \mathrm{mL})$ foram capazes de inibir de 5 a $15 \%$ a solubilização do colesterol. Os maiores percentuais de inibição foram dependentes do grau de hidrólise alto da proteína (ZHANG, YOKOYAMA e ZHANG, 2012). Hidrolisados da proteína do leite $(10 \mathrm{mg} / \mathrm{mL})$ reduziram $37 \%$ a solubilização do colesterol (NAGAOKA et al. 2001). Hidrolisados proteicos $(2 \mathrm{mg} / \mathrm{mL})$ de grão de bico foram recentemente descritos como capazes e inibir $50 \%$ da solubilização micelar do colesterol, também dependente do grau de hidrólise (35\% de grau de hidrólise) (DEL MAR YUST et al., 2012). Megías et al. (2009), utilizando o mesmo protocolo de digestão in vitro deste estudo, inibiram em $60 \%$ a solubilização do colesterol com apenas $1 \mathrm{mg} / \mathrm{mL}$ de proteína do girassol, mesma quantidade utilizada neste estudo.

\subsubsection{Hidrolisado proveniente da farinha de feijão extrusado (Fex)}

Conforme exposto na Tabela 7, foi observado que o hidrolisado da Fex inibiu a solubilização micelar, porém, esta ação não pode ser atribuída somente à fração proteica dada à menor pureza em proteína. Mesmo com interferentes, que não deixam clara a ação da proteína ou de qualquer outro componente nesse mecanismo, o modelo utilizando o hidrolisado da Fex se aproxima da realidade ao simular o consumo de um snack de feijão caupi atuando nas micelas de sais biliares, pois é um mecanismo supramolecular.

O processo de extrusão, empregando temperatura e força mecânica pode facilitar a liberação de sequencias peptídicas, compostos antioxidantes, fitoesteróis que após a hidrólise atuam de forma concomitante. Dessa forma, a extrusão pode ser utilizada como alternativa para melhorar a biodisponibilidade dos constituintes da matéria-prima que possuam efeitos bioativos na insolubilização micelar do colesterol (DEHGHAN-SHOAR et al., 2011; BRENNAN, MENARD, et al., 2012).

Compostos como epigalocatequina galato e fitoesteróis, presentes em feijões, são potentes inibidores da solubilização micelar de colesterol. Os fitoesteróis não esterificados possuem capacidade de inibir $50 \%$ da solubilidade do colesterol nas micelas mistas (BROWN et al., 2010). Por serem mais apolares, atuam como 
competidores pelo espaço intramicelar. Esses compostos aumentam o volume e tamanho das micelas resultantes, inviabilizando o reconhecimento e absorção pelas vilosidades intestinais (ARTS e HOLLMAN, 1998; RAEDERSTORFF et al., 2003; JESCH e CARR, 2006).

Tradicionalmente consumido na China, o molusco Corbicula Flumínea foi preparado na forma mais usual de consumo (cozimento) e hidrolisado integralmente, mostrou-se capaz de inibir $18,5 \%$ da solubilização micelar do colesterol (LIN et al., 2010).

Em geral, pode-se afirmar que a capacidade dos hidrolisados de insolubilizar o colesterol foi melhorada pelo processamento térmico. Ressalta-se, a escassez de estudos com matérias-primas processadas termicamente.

\section{CONCLUSÕES}

A temperatura e a interação entre as variáveis independentes são determinantes na razão de expansão radial nas condições testadas.

Independente do processamento, os hidrolisados do feijão caupi são capazes de inibir a enzima HMGR e reduzir a solubilização micelar do colesterol in vitro.

A capacidade dos hidrolisados de insolubilizar o colesterol foi melhorada pelo cozimento em autoclave e pela extrusão.

As vias testadas são alteradas pela proteína do feijão caupi, porém, não são descartadas outras vias e mecanismos envolvidos na inibição.

Apesar de mostrar resultados promissores, mais estudos precisam ser realizados considerando as variáveis da extrusão nos mecanismos biológicos, além de identificar quais são os componentes dos hidrolisados responsáveis por essa ação. 


\section{REFERÊNCIAS}

ALONSO, R. et al. Effect of extrusion cooking on structure and functional properties of pea and kidney bean proteins. Journal of the Science of Food and Agriculture v. 80, n. 3, p. 397-403, 2000

ALSAFFAR, A. A. Effect of food processing on the resistant starch content of cereals and cereal products - a review. International Journal of Food Science and Technology, v. 46, n. 3, Mar 2011.

ALVAREZ-ALVAREZ, J. et al. Effects of extrusion, boiling, autoclaving, and microwave heating on lupine allergenicity. Journal of Agricultural and Food Chemistry, v. 53, n. 4, Feb 232005.

ALVIM, I. D.; SGARBIERI, V. C.; CHANG, Y. K. Desenvolvimento de farinhas mistas extrusadas à base de farinha de milho, derivados de levedura e caseína. Ciência e Tecnologia de Alimentos, v. 22, p. 170-176, 2002.

ANUONYE, J. C. et al. Nutrient and antinutrient composition of extruded acha/soybean blends. Journal of Food Processing and Preservation, v. 34, May 2010.

AOAC. Official methods of analysis of the Association of Official Analytical Chemists. Inc th Wash DC, v. 18, 2010.

ARNOLDI, A. et al. Soy protein components active in the regulation of cholesterol homeostasis. Biologically-Active Phytochemicals in Food, n. 269, p. 103-106, 2001.

ARTS, I. C. W.; HOLLMAN, P. C. H. Optimization of a quantitative method for the determination of catechins in fruits and legumes. Journal of Agricultural and Food Chemistry, v. 46, n. 12, p. 5156-5162, Dec 1998.

ARÊAS, J.A.G. Interações moleculares do amido durante o processo de extrusão.Bol. SBCTA v. 30, p. 28-30, 1996

ASARE, E. K. et al. Modelling the effects of feed moisture and ingredient variations on the physical properties and functional characteristics of extruded sorghum-groundnut-cowpea blends using response surface methodology. International Journal of Food Engineering, v. 6 , n. 4,2010 a.

Response surface methodology for studying the effects of feed moisture and ingredient variations on the chemical composition and appearance of extruded sorghumgroundnut-cowpea blends. International Journal of Food Engineering, v. 6, n. 6, p. 23, 2010b.

Extrusion cooking of rice-groundnut-cowpea mixtures - effects of extruder characteristics on nutritive value and physico-functional properties of extrudates using response surface methodology. Journal of Food Processing and Preservation, v. 36, n. 5, Oct 2012. 
AVANZA, M. et al. Nutritional and anti-nutritional components of four cowpea varieties under thermal treatments: Principal component analysis. Lwt-Food Science and Technology, v. 51, n. 1, p. 148-157, Apr 2013.

BARRROS NETO, B.; SCARMINIO, I. S.; BRUNS, R. E. Como fazer experimentos: pesquisa e desenvolvimento na ciência e na indústria. Editora da UNICAMP, 2003. 401.

BATISTA, K. A.; PRUDENCIO, S. H.; FERNANDES, K. F. Changes in the biochemical and functional properties of the extruded hard-to-cook cowpea (Vigna unguiculata L. Walp). International Journal of Food Science and Technology, v. 45, n. 4, p. 794-799, 2010.

BATISTUTI, J. P.; BARROS, R. M. C.; AREAS, J. A. G. Optimization of extrusion cooking process for chickpea (Cicer-arietinum, I) defatted flour by response-surface methodology. Journal of Food Science, v. 56, n. 6, p. 1695, 1991.

BIASUTTI, E. A. R. et al. Action of pancreatin for obtaining whey protein hydrolysates with high oligopeptide contents. Revista Brasileira De Ciencias Farmaceuticas, v. 44, n. 1, p. 51-60, Jan-Mar 2008.

BLIGH, E. G.; DYER, W. J. A rapid method of total lipid extraction and purification. Canadian Journal of Biochemistry and Physiology, v. 37, n. 8, p. 911-917, 1959.

BOMBO TREVISAN, A. J.; GOMES AREAS, J. A. Development of corn and flaxseed snacks with high-fibre content using response surface methodology (RSM). International Journal of Food Sciences and Nutrition, v. 63, n. 3, p. 362-367, May 2012.

BOX, G. E. P.; DRAPER, N. R. Empirical model-building and response surfaces. Wiley, 1987.

BRASIL. Guia alimentar para a população brasileira: promovendo a alimentação saudável. Ministério da Saúde.Coordenação-Geral da Política de Alimentação e Nutrição, 2006.

BRENNAN, M. A. et al. Enrichment of extruded snack products with coproducts from chestnut mushroom (Agrocybe aegerita) production: Interactions between dietary fiber, physicochemical characteristics, and glycemic load. Journal of Agricultural and Food Chemistry, v. 60, n. 17, p. 4396-4401, May 2012.

Ready-to-eat snack products: the role of extrusion technology in developing consumer acceptable and nutritious snacks. International Journal of Food Science \& Technology, v. 48, n. 5, p. 893-902, 2013.

Impact of dietary fibre-enriched ready-to-eat extruded snacks on the postprandial glycaemic response of non-diabetic patients. Molecular Nutrition \& Food Research, v. 56, n. 5, p. 834-837, May 2012a.

Amaranth, millet and buckwheat flours affect the physical properties of extruded breakfast cereals and modulates their potential glycaemic impact. Starch-Starke, v. 64, n. 5, p. 392-398, May 2012b.

BROWN, A. W. et al. Phytosterol ester constituents affect micellar cholesterol solubility in model bile. Lipids, v. 45, n. 9, p. 855-862, Sep 2010.

CAMIRE, M. E.; DOUGHERTY, M. P.; BRIGGS, J. L. Functionality of fruit powders in extruded corn breakfast cereals. Food Chemistry, v. 101, n. 2, p. 765-770, 2007. 
CAMPOS, M. R. S.; GUERRERO, L. A. C.; ANCONA, D. A. B. Angiotensin-I converting enzyme inhibitory and antioxidant activities of peptide fractions extracted by ultrafiltration of cowpea Vigna unguiculata hydrolysates. Journal of the Science of Food and Agriculture, v. 90, n. 14, p. 2512-2518, Nov 2010.

CARBONARO, M.; VECCHINI, P.; CARNOVALE, E. Protein solubility of raw and cooked beans (Phaseolus vulgaris): role of the basic residues. Journal of agricultural and food chemistry, v. 41, n. 8, p. 1169-1175, 1993.

CARDOSO SANTIAGO, R. A. et al. The potential of extruded chickpea, corn and bovine lung for malnutrition programs. Nutritionists meet Food Scientists and Technologists (Part 2), v. 2, n. 3, p. 203-209, 2001.

CHAKRABORTY, S. K. et al. Process optimization with respect to the expansion ratios of millet- and legume (Pigeon pea)-based extruded snacks. Journal of Food Process Engineering, v. 34, n. 3, p. 777-791, Jun 2011.

CHANG, Y. K. et al. The influence of specific mechanical energy on cornmeal viscosity measured by an on-line system during twin-screw extrusion. Brazilian Journal of Chemical Engineering, v. 16, n. 3, p. 285-295, 1999.

CHAVEZ-JAUREGUI, R. N. et al. Acceptability of snacks produced by the extrusion of amaranth and blends of chickpea and bovine lung. International Journal of Food Science and Technology, v. 38, n. 7, p. 795-798, 2003.

CHAVEZ-JAUREGUI, R. N.; SILVA, M.; AREAS, J. A. G. Extrusion cooking process for amaranth (Amaranthus caudatus L.). Journal of Food Science, v. 65, n. 6, p. 1009-1015, 2000.

CHEN, X.; NIU, J.; CUI, Y. In vitro digestion/centrifugal ultrafiltration to determine the oral bioavailability of lead in soils. Journal of Food Agriculture \& Environment, v. 10, n. 1, p. 681-684, Jan 2012.

CHEVREUIL, L. R. et al. Detecção de inibidores de tripsina e atividade hemaglutinante em sementes de leguminosas arbóreas da amazônia. Acta Amazonica, v. 39, p. 199-205, 2009.

CIAN, R. E.; LUGGREN, P.; DRAGO, S. R. Effect of extrusion process on antioxidant and ACE inhibition properties from bovine haemoglobin concentrate hydrolysates incorporated into expanded maize products. International Journal of Food Sciences and Nutrition, v. 62, n. 7, p. 774-780, Nov 2011.

CONTI E SILVA, A. C.; DA CRUZ, R. J.; AREAS, J. A.G. Influence of thermoplastic extrusion on the nutritive value of bovine rumen protein. Meat Science, v. 84, n. 3, Mar 2010.

CORETA-GOMES, F. M. et al. Quantification of cholesterol solubilized in bile salt micellar aqueous solutions using C-13 nuclear magnetic resonance. Analytical Biochemistry, v. 427, n. 1, p. 41-48, Aug 12012.

COSKUN, A.; SERTESER, M.; UNSAL, I. Inhibition of cholesterol biosynthesis in hypercholesterolemia - is it the right choice? Journal of Medical Biochemistry, v. 32, n. 1, p. 16-19, Jan-Mar 2013. 
DE PILLI, T. et al. Starch-lipid complex formation during extrusion-cooking of model system (rice starch and oleic acid) and real food (rice starch and pistachio nut flour). European Food Research and Technology, v. 234, n. 3, Mar 2012.

DEHGHAN-SHOAR, Z. et al. Lycopene bioaccessibility and starch digestibility for extruded snacks enriched with tomato derivatives. Journal of Agricultural and Food Chemistry, v. 59, n. 22, Nov 232011.

DEL MAR YUST, M. et al. Hypocholesterolaemic and antioxidant activities of chickpea (Cicer arietinum L.) protein hydrolysates. Journal of the Science of Food and Agriculture, v. 92, n. 9, p. 1994-2001, Jul 2012.

DESCAMPS, O. S. et al. Where does the interplay between cholesterol absorption and synthesis in the context of statin and/or ezetimibe treatment stand today? Atherosclerosis, v. 217, n. 2, p. 308-321, Aug 2011.

DURÁN C, R.; VALENZUELA B, A. La experiencia japonesa con los alimentos FOSHU: ¿los verdaderos alimentos funcionales? Revista chilena de nutrición, v. 37, p. 224-233, 2010.

DZIUBA, J.; IWANIAK, A.; MINKIEWICZ, P. Computer-aided characteristics of proteins as potential precursors of bioactive peptides. Polimery, v. 48, n. 1, p. 50-53, 2003.

EMBRAPA. Unidade de execução de âmbito estadual de Rio Branco.Cultura do caupi no estado do Acre.: Folder 1987.

ERDMANN, K.; CHEUNG, B. W. Y.; SCHRODER, H. The possible roles of food-derived bioactive peptides in reducing the risk of cardiovascular disease. Journal of Nutritional Biochemistry, v. 19, n. 10, p. 643-654, 2008.

FAUBION, J. M.; HOSENEY, R. C. High-temperature short-time extrusion cooking of wheatstarch and flour .1. Effect of moisture and flour type on extrudate properties. Cereal Chemistry, v. 59, n. 6, p. 529-533, 19821982.

FERNANDES, M. S. et al. Efeito da temperatura de extrusão na absorção de água, solubilidade e dispersibilidade da farinha pré-cozida de milho-soja (70:30). Ciência e Tecnologia de Alimentos, v. 23, p. 234-239, 2003.

FERREIRA, E. D. et al. Soy beta-conglycinin (7S globulin) reduces plasma and liver cholesterol in rats fed hypercholesterolemic diet. Journal of Medicinal Food, v. 14, n. 1-2, p. 94-100, Jan 2011.

FITZGERALD, C. et al. Heart health peptides from macroalgae and their potential use in functional foods. Journal of Agricultural and Food Chemistry, v. 59, n. 13, p. 6829-6836, Jul 2011.

FREIRE FILHO, F. R. et al. Características botânicas e agronômicas de cultivares de feijão macassar (Vigna unguiculata (L.) Walp.). (EMBRAPA-UEPAE de Teresina. Boletim de Pesquisa, 4). Teresina: 45 p. 1981.

FROTA, K. D. M. G. Efeito do feijão caupi (Vigna unguiculata L. Walp) e da proteína isolada no metabolismo lipídico em hamsters hipercolesterolemizados. 2007. Dissertação (Mestrado em Nutrição Humana Aplicada) Universidade de São Paulo, São Paulo. 
FROTA, K. D. M. G. et al. Utilização da farinha de feijão-caupi (Vigna unguiculata L. Walp) na elaboração de produtos de panificação. Ciência e Tecnologia de Alimentos, v. 30, p. 44-50, 2010.

FROTA, K. M. G. Efeito da proteína de feijão caupi (Vigna unguiculata L. Walp) nos marcadores de risco para doença cardiovascular em pacientes hipercolesterolêmicos. 2011. Dissertação (Mestrado Nutrição em Saúde Pública) Universidade de São Paulo, São Paulo.

FROTA, K. M. G. et al. Cholesterol-lowering properties of whole cowpea seed and its protein isolate in hamsters. Journal of Food Science, v. 73, n. 9, p. H235-H240, 2008.

FROTA, K. D. M. G; SOARES, R. A. M; AREAS, J. A.G Chemical composition of cowpea (Vigna unguiculata L. Walp), BRS-Milenio cultivar. Ciencia E Tecnologia De Alimentos, v. 28, n. 2, p. 470-476, Apr-Jun 2008.

GHASSEM, M.; ARIHARA, K.; BABJI, A. S. Isolation, purification and characterisation of angiotensin I-converting enzyme-inhibitory peptides derived from catfish (Clarias batrachus) muscle protein thermolysin hydrolysates. International Journal of Food Science and Technology, v. 47, n. 11, p. 2444-2451, Nov 2012.

GHOLAMHOSEINIAN, A.; SHARIFI-FAR, F.; SHAHOUZEHI, B. Inhibitory activity of some plant methanol extracts on 3-hydroxy-3-methylglutaryl coenzyme a reductase. 2010.

GOLDSTEIN, J. L.; BROWN, M. S. Regulation of the mevalonate pathway. Nature, v. 343, n. 6257, p. 425-430, 1990.

HARPER, J. M. Extrusion of foods. United States: 1981. 212 ISBN 0-8493-5203-3.

HERNANDEZ-LEDESMA, B.; CONTRERAS, M. D.; RECIO, I. Antihypertensive peptides: Production, bioavailability and incorporation into foods. Advances in Colloid and Interface Science, v. 165, n. 1, p. 23-35, Jun 2011.

HOYLE, N. T.; MERRITT, J. H. Quality of fish-protein hydrolysates from herring (Clupeaharengus). Journal of Food Science, v. 59, n. 1, p. 76-\&, Jan-Feb 1994.

$\mathrm{HU}, \mathrm{Y}$. et al. Concentrations of biogenic amines in fish, squid and octopus and their changes during storage. Food Chemistry, v. 135, n. 4, Dec 152012.

HUANG, S. L. et al. Dipeptidyl-peptidase IV inhibitory activity of peptides derived from tuna cooking juice hydrolysates. Peptides, v. 35, n. 1, p. 114-121, May 2012.

IBGE - INSTITUTO BRASILEIRO DE GEOGRAFIA E ESTATÍSTICA. Sistema IBGE de recuperação automatica - SIDRA: Banco de dados agregados 2002.

IKONEN, E. Cellular cholesterol trafficking and compartmentalization. Nature Reviews Molecular Cell Biology, v. 9, n. 2, p. 125-138, Feb 2008.

ILO, S.; REGINE, S.; BERGHOFE, E. Role of lipids in the extrusion cooking processes. Grasas y Aceites.v.51, n 1-2, p.97.2000.

INSTITUTO BRASILEIRO DE GEOGRAFIA, E. E. Sistema IBGE de recuperação automatica - SIDRA: Banco de dados agregados 2002. 
ISTVAN, E. S.; DEISENHOFER, J. Structural mechanism for statin inhibition of HMG-CoA reductase. Science, v. 292, n. 5519, p. 1160-1164, May 2001.

IVANOV, V. T. et al. Hemoglobin as a source of endogenous bioactive peptides: The concept of tissue-specific peptide pool. Biopolymers - Peptide Science Section, v. 43, n. 2, p. 171-188, 1997.

JESCH, E. D.; CARR, T. P. Sitosterol reduces micellar cholesterol solubility in model bile. v. 26, n. 11, p. 579-584, 2006.

KELKAR, S. et al. Use of low-temperature extrusion for reducing phytohemagglutinin activity (PHA) and oligosaccharides in beans (Phaseolus vulgaris L.) cv. Navy and Pinto. Food Chemistry, v. 133, n. 4, p. 1636-1639, Aug 2012.

KIDAMBI, S.; PATEL, S. B. Cholesterol and non-cholesterol sterol transporters: ABCG5, ABCG8 and NPC1L1: a review. Xenobiotica, v. 38, n. 7-8, p. 1119-1139, 2008.

KRAUGERUD, O. F.; JØRGENSEN, H. Y.; SVIHUS, B. Physical properties of extruded fish feed with inclusion of different plant (legumes, oilseeds, or cereals) meals. Animal Feed Science and Technology.v. 163, n. 2-4, p. 244-254, 2011.

KWAK, J. H. et al. Weight reduction effects of a black soy peptide supplement in overweight and obese subjects: Double blind, randomized, controlled study. Food \& Function, v. 3, n. 10, p. 1019-1024, Oct 2012.

LACHENMEIER, D. et al. NMR evaluation of total statin content and HMG-CoA reductase inhibition in red yeast rice (Monascus spp.) food supplements. v. 7, n. 1, p. 8, 2012.

LANDETE , J. M. Updated knowledge about polyphenols: Functions, bioavailability, metabolism, and health. Critical Reviews in Food Science and Nutrition Vol. 52, Iss. 10, 2012.

LIN, Y.-H. et al. Hypocholesterolemic effect of compounded freshwater clam protein hydrolysate and Gracilaria. Food Chemistry, v. 123, n. 2, p. 395-399, Nov 152010.

LINSBERGER-MARTIN, G. et al. High hydrostatic pressure influences antinutritional factors and in vitro protein digestibility of split peas and whole white beans. Lwt-Food Science and Technology, v. 51, n. 1, p. 331-336, Apr 2013.

LIRA FILHO, J. F. D. Efeitos da extrusão termoplástica sobre as propriedades tecnológicas e nutritivas das proteínas da farinha integral do feijão caupi (Vigna uinguiculata (L.) Walp). 2001. 165 (Tese de Doutorado). Faculdade de Engenharia de Alimentos, Universidade Estadual de Campinas - UNICAMP, Campinas - SP.

LOWRY, O. H., et al. (1951) Protein measurement with the folin phenol reagent. Journal of Biological Chemistry, 193(1), pp.265-275.

MAHASUKHONTHACHAT, K.; SOPADE, P. A.; GIDLEY, M. J. Kinetics of starch digestion and functional properties of twin-screw extruded sorghum. Journal of Cereal Science, v. 51, n. 3, p. 392-401, 2010.

MARMESAT, S. et al. Influence of fatty acid composition on chemical changes in blends of sunflower oils during thermoxidation and frying. Food Chemistry, v. 135, n. 4, Dec 152012. 
MARQUES, M. R. et al. An in vitro analysis of the total phenolic content, antioxidant power, physical, physicochemical, and chemical composition of Terminalia Catappa Linn fruits. Ciência e Tecnologia de Alimentos, v. 32, p. 209-213, 2012.

MARRINK, S. J.; MARK, A. E. Molecular dynamics simulations of mixed micelles modeling human bile. Biochemistry, v. 41, n. 17, p. 5375-5382, Apr 302002.

MATHEW, A. et al. Alzheimer's disease: Cholesterol a menace?.Brain Research Bulletin, v. 86, n. 1-2, p. 1-12, 2011.

MEGIAS, C. et al. sunflower protein hydrolysates reduce cholesterol micellar solubility. Plant Foods for Human Nutrition, v. 64, n. 2, p. 86-93, Jun 2009.

MEGÍAS, C. et al. Stability of sunflower protein hydrolysates in simulated gastric and intestinal fluids and Caco-2 cell extracts. Food Science and Technology, v. 42, n. 9, p. 1496-1500, 2009.

MONTGOMERY, D. C.; RUNGER, G. C. Applied statistics and probability for engineers. Wiley, 2010. ISBN 0470053046.

MOREIRA-ARAUJO, R. S. R.; ARAUJO, M. A. M.; AREAS, J. A. G. Fortified food made by the extrusion of a mixture of chickpea, corn and bovine lung controls iron-deficiency anaemia in preschool children. Food Chemistry, v. 107, n. 1, p. 158-164, 2008.

MORRISON, W. R.; SMITH, L. M. Preparation of fatty acid methyl esters + dimethylacetals from lipids with boron fluoride-methanol. Journal of Lipid Research, v. 5, n. 4, p. 600-\&, 1964.

MOUSINHO, F. E. P. Viabilidade econômica do feijão caupi no Estado do Piauí. 2005. Tese (Doutorado em Irrigação e Drenagem)-Escola Superior de Agricultura" Luiz de Queiroz", Universidade de São Paulo, Piracicaba.

NAGAOKA, S. et al. Identification of novel hypocholesterolemic peptides derived from bovine milk beta-lactoglobulin. Biochemical and Biophysical Research Communications, v. 281, n. 1, p. 11-17, 2001.

NES, W. D. Biosynthesis of cholesterol and other sterols. Chemical Reviews, v. 111, n. 10, p. 6423-6451, Oct 2011.

OLIVEIRA, L. G. D. et al. Inibidores de proteases encontrados em sementes de Caesalpinia echinata (paubrasil): isolamento e caracterização do inibidor de tripsina. Revista Brasileira de Farmacognosia, v. 12, p. 72-74, 2002.

PAK, V. V. et al. Peptide design of a competitive inhibitor for HMG-CoA reductase based on statin structure. Biopolymers, v. 84, n. 6, p. 586-594, 2006.

Structure-activity relationships of the peptide Ile-Ala-Val-Pro and its derivatives revealed using the semi-empirical AM1 method. Chemistry of Natural Compounds, v. 41, n. 4, p. 454-460, Jul-Aug 2005a.

Isolation and identification of peptides from soy 11S-globulin with hypocholesterolemic activity. Chemistry of Natural Compounds, v. 41, n. 6, p. 710-714, Nov-Dec 2005b. 
PEREIRA, Railene de Azevedo. Inibidores protéicos e seu potencial uso no controle de insetos-praga de importância para a cultura do café e do feijão. 2005. 169 f., il. Tese (Doutorado em Biologia Molecular)-Universidade de Brasília, Brasília, 2005.

PETRUZZELLI, M. et al. Micellar lipid composition profoundly affects LXR-dependent cholesterol transport across CaCo2 cells. Febs Letters, v. 583, n. 8, p. 1274-1280, Apr 17 2009.

PIMENTA, D. C.; LEBRUN, I. Cryptides: Buried secrets in proteins. Peptides, v. 28, n. 12, p. 2403-2410, Dec 2007.

POPJAK., G. In: PRESS, P. (Ed.). Lipids: Chemistry, Biochemistry and Nutrition. New York: Mead, J. F., Alfin-Slater, R. B., Howton, D. R., Popjak., G.,, 1986. p.296.

POTTER, S. M. Soy protein and cardiovascular disease: the impact of bioactive components in soy. Nutrition Reviews, v. 56, n. 8, p. 231-235, 1998.

PRUDENCIO-FERREIRA, S. H.; AREAS, J. A. G. Protein-protein interactions in the extrusion of soya at various temperatures and moisture contents. Journal of Food Science, v. 58, n. 2, p. 378-\&, Mar-Apr 1993.

PRZYBYLSKI, R.; ALADEDUNYE, F. Formation of \&lt;i\&gt;Trans\&lt;/i\&gt; Fats During Food Preparation. Canadian Journal of Dietetic Practice and Research, v. 73, n. 2, p. 98-101, 2012.

RAEDERSTORFF, D. G. et al. Effect of EGCG on lipid absorption and plasma lipid levels in rats. v. 14, n. 6, p. 326-332, 2003.

REDGWELL, R. J. et al. Extrusion-Induced Changes to the Chemical Profile and Viscosity Generating Properties of Citrus Fiber. Journal of Agricultural and Food Chemistry, v. 59, n. 15, Aug 102011

RUTHERFURD, S. M. Methodology for determining degree of hydrolysis of proteins in hydrolysates: A review. Journal of Aoac International, v. 93, n. 5, p. 1515-1522, Sep-Oct 2010.

SAELEAW, M.; DURRSCHMID, K.; SCHLEINING, G. The effect of extrusion conditions on mechanical-sound and sensory evaluation of rye expanded snack. Journal of Food Engineering, v. 110, n. 4, p. 532-540, Jun 2012.

SATO, K.; HEGARTY, G. R. Warmed-over flavor in cooked meats. Journal of Food Science, v. 36, n. 7, p. 1098-1102, 1971.

SAUNDERS, R. M. et al. Measurement of digestibility of alfalfa protein concentrates by in vivo and in vitro methods. Journal of Nutrition, v. 103, n. 4, p. 530-535, 1973.

SEGURA-CAMPOS, M. et al. Bioavailability of bioactive peptides. Food Reviews International, v. 27, n. 3, p. 213-226, 2011.

SEGURA-CAMPOS, M. R.; CHEL-GUERRERO, L. A.; BETANCUR-ANCONA, D. A. Purification of angiotensin l-converting enzyme inhibitory peptides from a cowpea (Vigna unguiculata) enzymatic hydrolysate. Process Biochemistry, v. 46, n. 4, p. 864-872, Apr 2011. 
SILVEIRA, Z. C. Análise estatística e otimização de parâmetros de projeto em componentes mecânicos. 2003. Tese, Departamento de Engenharia Mecância, Universidade Estadual de Campinas, Campinas

SILVESTRE, M. P. C.; HAMON, M.; YVON, M. Analysis of protein hydrolysates .2. characterization of casein hydrolysates by a rapid peptide quantification method. Journal of Agricultural and Food Chemistry, v. 42, n. 12, p. 2783-2789, Dec 1994.

SINGH, S.; GAMLATH, S.; WAKELING, L. Nutritional aspects of food extrusion: a review. International Journal of Food Science and Technology, v. 42, n. 8, p. 916-929, Aug 2007.

SOARES, R. A. M. Identificação de peptídeos hipocolesterolemizantes do isolado protéico do grão de amaranto (Amaranthus cruentus L. BRS-Alegria). 2008. (Dissertação (Mestrado em Nutrição em Saúde Pública). Universidade de São Paulo. Faculdade de Saúde Pública.

SORENSEN, M. et al. Pea and wheat starch possess different processing characteristics and affect physical quality and viscosity of extruded feed for Atlantic salmon. Aquaculture Nutrition, v. 17, n. 2, Apr 2011.

SWERGOLD, G. D.; RUBIN, C. S. High-performance gel-permeation chromatography of polypeptides in a volatile solvent - rapid resolution and molecular-weight estimations of proteins and peptides on a column of TSK-G3000-PW. Analytical Biochemistry, v. 131, n. 2, p. 295-300, 1983.

TACHIBANA, S. et al. Cholesterol and plant sterol efflux from cultured intestinal epithelial cells is mediated by ATP-binding cassette transporters. Bioscience Biotechnology and Biochemistry, v. 71, n. 8, p. 1886-1895, Aug 2007.

TSOU, M.-J. et al. Purification and identification of lipolysis-stimulating peptides derived from enzymatic hydrolysis of soy protein. Food Chemistry, v. 138, n. 2-3, p. 1454-1460, May 15 2013.

TSUZUKI, W. Study of the Formation of trans fatty acids in model oils (triacylglycerols) and edible oils during the heating process. Japan Agricultural Research Quarterly: JARQ. v. 46, n. 3, p. 215-220, 2012.

VAZ, L. C. M. A.; AREAS, J. A. G. Recovery and upgrading bovine rumen protein by extrusion: Effect of lipid content on protein disulphide cross-linking, solubility and molecular weight. Meat Science, v. 84, n. 1, p. 39-45, Jan 2010.

VIJAYALAKSHMI, M. A.; LEMIEUX, L.; AMIOT, J. High-performance size exclusion liquidchromatography of small molecular-weight peptides from protein hydrolysates using methanol as a mobile phase additive. Journal of Liquid Chromatography, v. 9, n. 16, p. 3559-3576, 1986.

WAKASA, Y. et al. The Hypocholesterolemic Activity of Transgenic Rice Seed Accumulating Lactostatin, a Bioactive Peptide Derived from Bovine Milk beta-Lactoglobulin. Journal of Agricultural and Food Chemistry, v. 59, n. 8, p. 3845-3850, Apr 2011.

WASZCZYNSKYJ, N.; RAO, C. S.; SILVA, R. S. F. D. Extraction of proteins from wheat bran: application of carbohydrases cellulase, hemicellulase, pectinase. Cereal Chemistry. v. $58,1981$. 
WOOLLETT, L. A. et al. Micellar solubilisation of cholesterol is essential for absorption in humans. Gut, v. 55, n. 2, p. 197-204, Feb 2006.

WRIGHT, D. J.; Bumstead, m. r. legume proteins in food-technology. Philosophical Transactions of the Royal Society of London Series B-Biological Sciences, v. 304, $\mathrm{n}$. 1120, p. 381-393, 1984.

$\mathrm{XIA}, \mathrm{Y}$. et al. Fractionation and characterization of antioxidant peptides derived from barley glutelin by enzymatic hydrolysis. Food Chemistry, v. 134, n. 3, p. 1509-1518, Oct 12012.

ZARZYCKI, P.; RZEDZICKI, Z. Changes in dietary fibre fractional composition of multi-cereal blends caused by extrusion. Int. Agrophysics, v. 23, p. 287-293.2009.

ZHANG, H.; YOKOYAMA, W. H.; ZHANG, H. Concentration-dependent displacement of cholesterol in micelles by hydrophobic rice bran protein hydrolysates. Journal of the Science of Food and Agriculture, v. 92, n. 7, p. 1395-1401, 2012. 
APÊNCIDE 1- Efeito da temperatura e da umidade da matéria-prima sobre a razão de expansão dos extrusados.

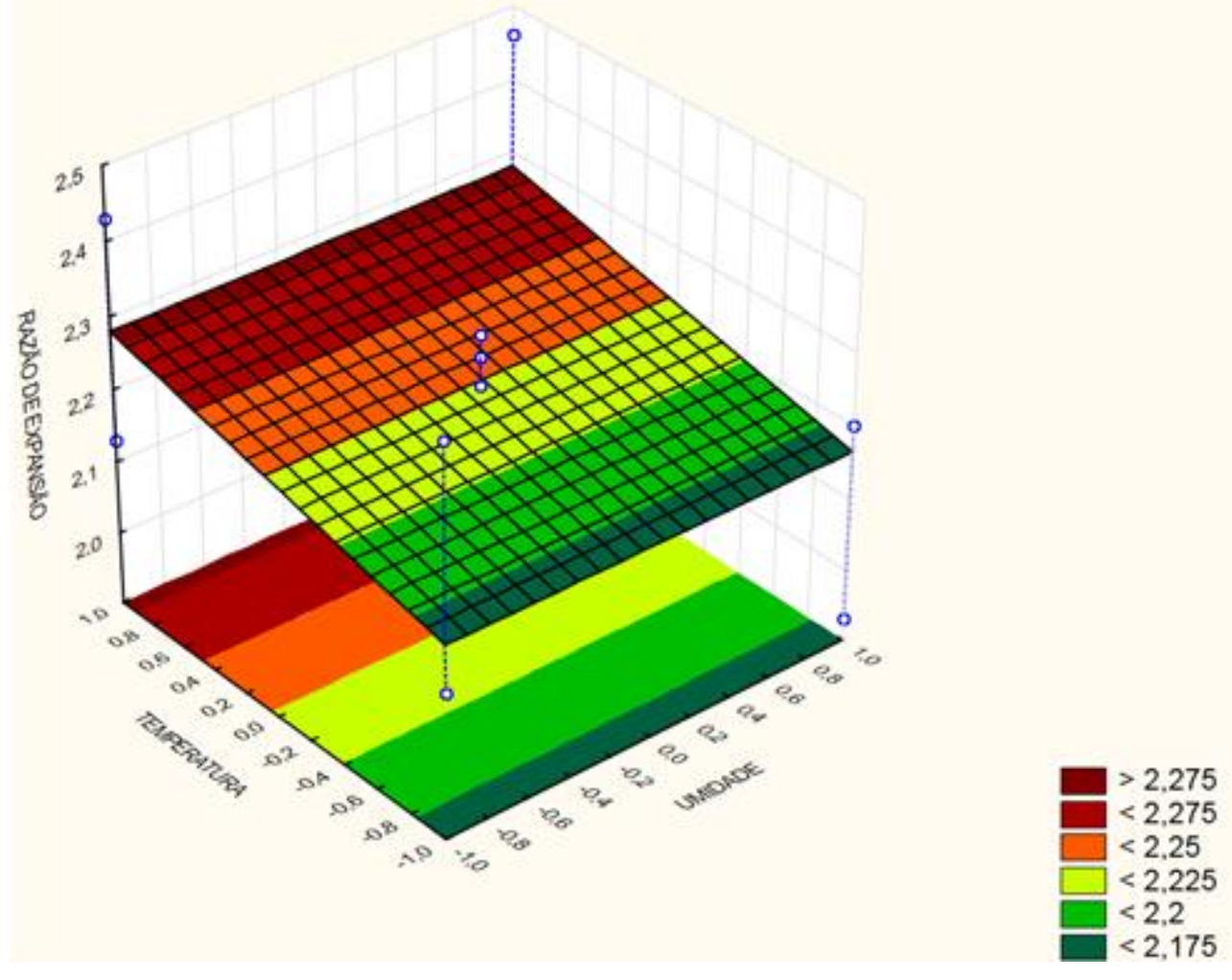


APÊNDICE 2- Efeito da temperatura e da velocidade de rotação da sobre a razão de expansão dos extrusados.

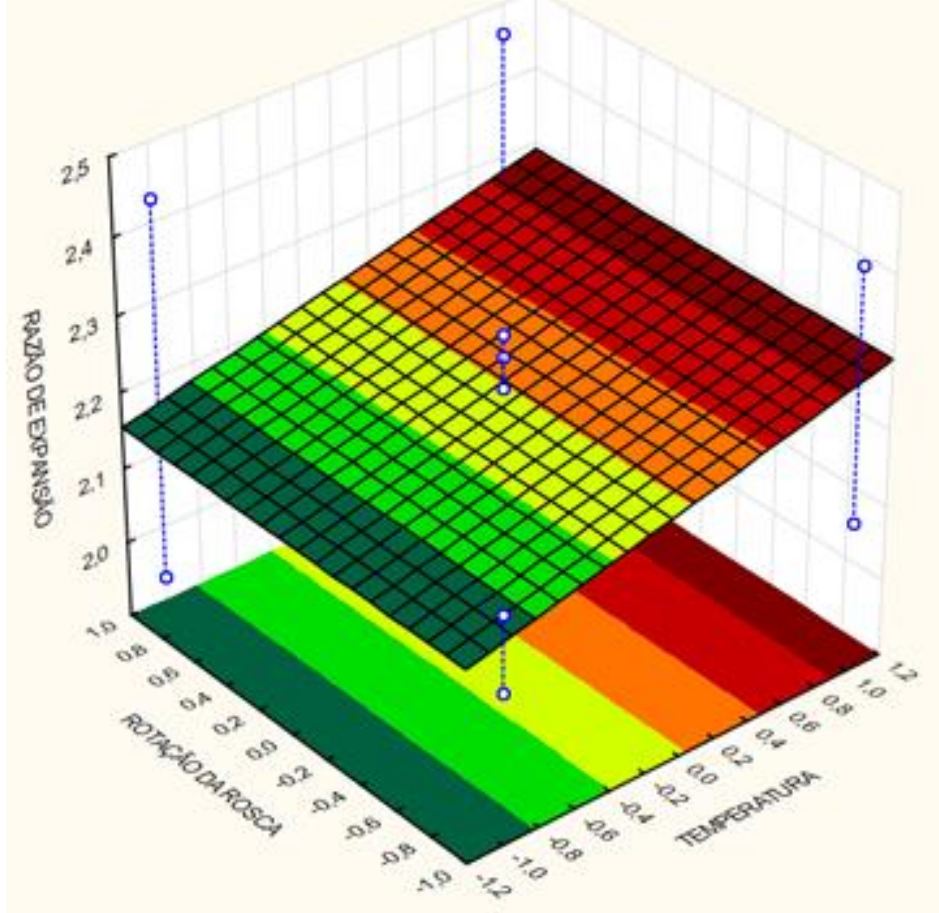


APÊNDICE 3-Estimativa dos efeitos das variáveis independetentes na razão de expansão da farinha extrusada de caupi.

\begin{tabular}{c|c|c}
\hline FATORES & EFEITO & SIGNIFICÂNCIA \\
\hline Média & 2,222500 & 0,000031 \\
\hline Curvatura & 0,088333 & 0,204333 \\
\hline$x_{1}$ & $-0,100000$ & 0,056492 \\
\hline$x_{2}$ & 0,030000 & 0,350481 \\
\hline$x_{3}$ & 0,115000 & 0,043602 \\
\hline$x_{1} x_{2}$ & 0,015000 & 0,607208 \\
\hline$x_{1} x_{3}$ & 0,100000 & 0,056492 \\
\hline$x_{2} x_{3}$ & 0,000000 & 1,000000 \\
\hline$x_{1} x_{2} x_{3}$ & 0,315000 & 0,006157 \\
\hline
\end{tabular}




\section{ANEXO 1 - CURRÍCULOS LATTES}

\section{Marcelo Rodrigues Marques}

Endereço para acessar este CV: http://lattes.cnpq.br/9941741350359479

Última atualização do currículo em 12/07/2013

Graduado em Nutrição pela Universidade Federal do Piauí - UFPI (2010) com Mestrado em andamento em Nutrição - USP (2011), possui experiência em Ciência e Tecnologia de alimentos, atuando principalmente nos seguintes temas: desenvolvimento de produtos alimentícios e processamento de alimentos, análises físico-químicas de alimentos, valor nutritivo, propriedades funcionais de alimentos e alimentos funcionais, hidrolisados proteicos e peptídeos bioativos, antioxidantes naturais presente em alimentos e extrusão termoplástica. (Texto informado pelo autor)

\section{Identificação}

\section{Nome}

Marcelo Rodrigues Marques

Nome em citações bibliográficas

MARQUES, M. R.; Marques, Marcelo Rodrigues

\section{Endereço}

\section{Endereço Profissional}

Faculdade de Saúde Pública- USP, Departamento de Nutrição.

Av Dr. Arnaldo 715

Cerqueira César

01246-904 - Sao Paulo, SP - Brasil

URL da Homepage: http://www.nutricao.fsp.usp.br/funcionais/

\section{Formação acadêmica/titulação}

\section{1}

Mestrado em andamento em Nutrição em Saúde Pública (Conceito CAPES 6).

Universidade de São Paulo, USP, Brasil.

Título: Ação hipocolesterolêmica de hidrolisados de feijões caupi (Vigna unguiculata L.

Walp),Orientador: (9) Jose Alfredo Gomes Areas.

Bolsista do(a): Fundação de Amparo à Pesquisa do Estado de São Paulo, FAPESP, Brasil.

Palavras-chave: feijão caupi; peptídeos hipocolesterolêmicos; extrusão termoplástica.

Grande área: Ciências Agrárias / Área: Ciência e Tecnologia de Alimentos / Subárea: Ciência de 
Alimentos.

Grande Área: Ciências Agrárias / Área: Ciência e Tecnologia de Alimentos / Subárea: Tecnologia de Alimentos / Especialidade: Tecnologia de Produtos de Origem Vegetal.

Grande Área: Ciências Biológicas / Área: Bioquímica / Subárea: Biologia Molecular.

Setores de atividade: Fabricação de Produtos Alimentícios; Alimentação.

2005 - 2010

Graduação em Nutrição.

Universidade Federal do Piauí, UFPI, Brasil.

Título: Anemia ferropriva em mulheres universitárias em idade fértil e fatores de risco.

Orientador: Regilda Saraiva dos Reis Moreira Araújo.

Bolsista do(a): Conselho Nacional de Desenvolvimento Científico e Tecnológico, CNPq, Brasil. 


\title{
José Alfredo Gomes Arêas
}

Bolsista de Produtividade em Pesquisa do CNPq - Nível $1 C$

Endereço para acessar este CV: http://lattes.cnpq.br/5885518243056121

Última atualização do currículo em 27/05/2013

Graduação em Farmácia e Bioquímica pela Universidade de São Paulo (1973), Mestrado em Ciências dos Alimentos pela Universidade de São Paulo (1979), Doutorado em Food Science, University of Nottingham, Inglaterra (1983), Pós-doutorado junto ao Biomembrane Unit, Dep. of Biochemistry, University of Oxford, Inglaterra (1990-1993). Vice-Presidente da SBCTA (2004-2005). Coordenador do Programa de Pós-graduação em Saúde Pública da FSP/USP (2001-2006). Coordenador da área de Alimentos da Fundação de Amparo à Pesquisa do Estado de São Paulo FAPESP (2001-2008). Membro do Comitê de Saúde Coletiva da CAPES (2004-2006). Atualmente Professor Titular da Universidade de São Paulo junto ao Dep. de Nutrição da Faculdade de Saúde Pública. Atua na área de Ciência e Tecnologia de Alimentos, Nutrição e Saúde Pública, Propriedades Funcionais de Alimentos, Biofísica de Alimentos, e Alimentos Funcionais. Temas principais de pesquisa: alimentos funcionais, alimentos e Saúde, peptídeos bioativos, metabolismo do colesterol, alimentos não convencionais, alimentos especiais, intervenções nutricionais, processamento de alimentos e valor nutritivo, emulsões alimentícias, ressonância magnética nuclear aplicada a alimentos, extrusão. (Texto informado pelo autor)

\section{Identificação}

\section{Nome}

José Alfredo Gomes Arêas

Nome em citações bibliográficas

ARÊAS, J. A. G.;Areas, J. A. G.;Arêas, J. A. G.;Arêas, José A. G.;Areas, Jose A. G.;ARÊAS, JOSÉ ALFREDO GOMES

\section{Endereço}

\author{
Endereço Profissional \\ Universidade de São Paulo, Faculdade de Saúde Pública, Departamento de Nutrição. \\ Av. Dr. Arnaldo, 715 \\ Cerqueira César \\ 01246-904 - Sao Paulo, SP - Brasil \\ Telefone: (11) 30617858 \\ Fax: (11) 30617705 \\ URL da Homepage: http://www.nutricao.fsp.usp.br/funcionais
}




\section{Formação acadêmica/titulação}

\section{6}

Livre-docência.

Universidade de São Paulo, USP, Brasil.

Título: Interrelação entre estrutura e textura de isolados proteicos de pulmão bovino, Ano de obtenção: 1986.

Palavras-chave: Propriedades Funcionais; Interação lípide-proteína; Extrusão termoplástica; Espectroscopia de Alimentos; Atividade de água; Proteínas alimentares.

Grande área: Ciências Agrárias / Área: Ciência e Tecnologia de Alimentos / Subárea: Tecnologia de Alimentos / Especialidade: Aproveitamento de Subprodutos.

Grande Área: Ciências Agrárias / Área: Ciência e Tecnologia de Alimentos / Subárea: Tecnologia de Alimentos / Especialidade: Tecnologia de Produtos de Origem Animal.

Grande Área: Ciências Agrárias / Área: Ciência e Tecnologia de Alimentos / Subárea: Ciência de Alimentos / Especialidade: Propriedades Funcionais de Alimentos.

Setores de atividade: Nutrição e Alimentação; Produção Animal, Inclusive Serviços Veterinários; Fabricação de Equipamentos de Instrumentação Médico-Hospitalares, Instrumentos de Precisão e Ópticos, Equipamentos Para Automação Industrial, Cronômetros e Relógios.

\section{0 - 1993}

Pós-Doutorado. University of Oxford.

Bolsista do(a): Conselho Nacional de Desenvolvimento Científico e Tecnológico, CNPq, Brasil. Grande área: Ciências Biológicas / Área: Biofísica / Subárea: Biofísica Molecular.

Grande Área: Ciências Agrárias / Área: Ciência e Tecnologia de Alimentos / Subárea: Ciência de Alimentos / Especialidade: Propriedades Funcionais de Alimentos.

Grande Área: Ciências Agrárias / Área: Ciência e Tecnologia de Alimentos / Subárea: Ciência de Alimentos / Especialidade: Química, Física, Fisico-Química e Bioquímica dos Alim. e das Mat-Primas Alimentares.

\section{0 - 1983}

Doutorado em Food Science.

University of Nottingham, NOTTINGHAM, Inglaterra.

Título: Influence of Lipid-protein Interactions on Characteristics of Extruded Offal Protein, Ano de obtenção: 1983.

Orientador: Ralston A Lawrie.

Bolsista do(a): Conselho Nacional de Desenvolvimento Científico e Tecnológico, CNPq, Brasil. Palavras-chave: Food Protein; Extrusion of Protein; Recovery of Abattoir; Functional Properties; Novel Products; Protein Upgrade.

Grande área: Ciências Agrárias / Área: Ciência e Tecnologia de Alimentos / Subárea: Tecnologia de Alimentos / Especialidade: Aproveitamento de Subprodutos.

Grande Área: Ciências Agrárias / Área: Ciência e Tecnologia de Alimentos / Subárea: Ciência de Alimentos / Especialidade: Química, Física, Fisico-Química e Bioquímica dos Alim. e das Mat-Primas Alimentares.

Grande Área: Ciências Agrárias / Área: Ciência e Tecnologia de Alimentos / Subárea: Ciência de Alimentos / Especialidade: Propriedades Funcionais de Alimentos.

Setores de atividade: Nutrição e Alimentação; Produção Animal, Inclusive Serviços Veterinários; Produtos e Processos Biotecnológicos.

\section{4 - 1979}

Mestrado em Ciências dos Alimentos (Conceito CAPES 7).

Universidade de São Paulo, USP, Brasil.

Título: Transformações do amido na banana nanica (Musa acuminata L.): Papel da fosforilase e fosfatase,Ano de Obtenção: 1979.

Orientador: (9) Franco Maria Lajolo.

Bolsista do(a): Coordenação de Aperfeiçoamento de Pessoal de Nível Superior, CAPES, Brasil.

Palavras-chave: Amadurecimento; Amido; Banana; Fisiologia Pós-colheita.

Grande área: Ciências Agrárias / Área: Ciência e Tecnologia de Alimentos / Subárea: Ciência de 
Alimentos / Especialidade: Química, Física, Fisico-Química e Bioquímica dos Alim. e das Mat-Primas Alimentares.

Grande Área: Ciências Agrárias / Área: Ciência e Tecnologia de Alimentos / Subárea: Ciência de Alimentos / Especialidade: Fisiologia Pós-Colheita.

Grande Área: Ciências Agrárias / Área: Ciência e Tecnologia de Alimentos / Subárea: Ciência de Alimentos.

Setores de atividade: Produção Vegetal.

1969 - 1973

Graduação em Farmácia e Bioquímica.

Universidade de São Paulo, USP, Brasil. 